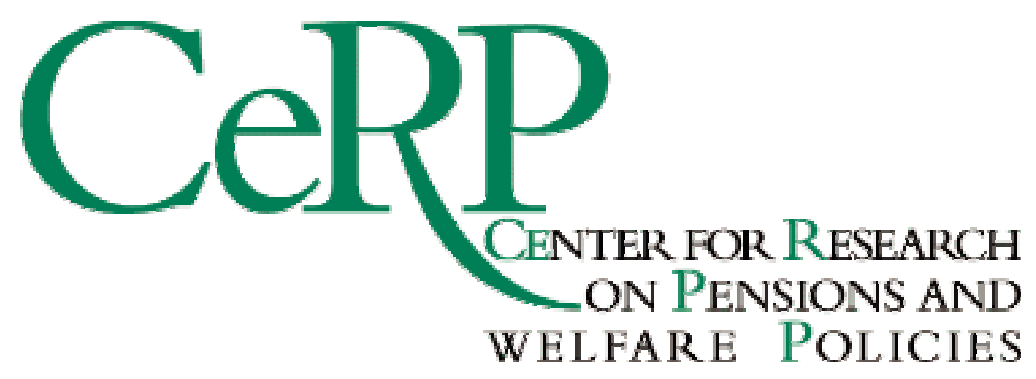

Working Paper 44/05

\title{
ADVERTISING AND PORTFOLIO CHOICE
}

\author{
Henrik Cronqvist
}




\title{
Advertising and Portfolio Choice*
}

\author{
Henrik Cronqvist ${ }^{* *}$ \\ The Ohio State University \\ Fisher College of Business \\ Department of Finance
}

This draft: November 1, 2005

\begin{abstract}
Using a unique large-scale event, the year 2000 launch of a privatized social security system involving individual savings accounts in Sweden, I report empirical evidence on the link between fund advertising and people's fund and portfolio choices. First, content analysis reveals that a very small portion of ads can be construed as directly informative about characteristics relevant for rational mutual fund investors, such as funds' expense ratios. Second, higher levels of advertising expenditures do not appear to signal ex ante higher unobservable fund manager quality or talent. Third, fund advertising affects people's portfolio choices, even when advertising does not appear to contain any information. Finally, fund advertising steers people to portfolios with lower returns and higher risk. My results have important implications for a welfare analysis of fund advertising and portfolio choices, asset pricing models, and mutual fund industry policy making, and may serve as a starting point for wider and more formal analysis of the effects of advertising, marketing, and persuasion in financial markets.
\end{abstract}

JEL classification: G11; G18; G23; M37

Keywords: Portfolio choice; Individual investor behavior; Mutual funds; Advertising

\footnotetext{
* This paper is my dissertation from The University of Chicago Graduate School of Business. I want to thank my committee members Nicholas Barberis, Anil Kashyap, Tobias Moskowitz, Per Strömberg, and Richard Thaler for their comments. I am deeply indebted to my chair, Richard Thaler, for his enthusiasm and for encouraging me to pursue research in this area. The suggestions by seminar participants at Boston College, Chicago GSB, CMU, Cornell, Emory, HBS, Michigan, the Ministry of Finance of Sweden, Notre Dame, Ohio State, UNC, University of Turin, and the joint University of Oregon and JFE Conference on Delegated Portfolio Management have been of significant help in revising an early draft. The comments by Eugene Fama, Richard Green, Milton Harris, David Hirshleifer, Roni Michaely, Wayne Mikkelson, Mattias Nilsson, Jeffrey Pontiff, Laura Starks, René Stulz, and Frank Yu were particularly helpful. I acknowledge financial support from Dr. Marcus Wallenberg's Foundation. Finally, I want to thank all the providers of data that have made this research possible, in particular the Premium Pension Authority, MarketWatch, and the National Library of Sweden. Any remaining errors are mine.

** E-mail address: henrik.cronqvist@cob.osu.edu.
} 


\section{Introduction}

Advertising is an increasingly important phenomenon in the mutual fund industry. More and more funds launch large campaigns, involving expensive newspaper advertisements or television commercials. There is also anecdotal evidence that funds aggressively try to recruit “brand managers” from successful retailers such as e.g. Taco Bell (e.g., Brandstrader (1996)). Statistics show that funds, in the U.S. alone, now spend more than 6 billion dollars on advertising annually, about ten times more than a decade ago. Despite the importance of advertising as a phenomenon in the mutual fund industry, financial economists have paid almost no attention to it. In this article, I fill this gap in the literature by asking the following question: does fund advertising affect people’s portfolio choices?

The mere size and scope of the fund advertising phenomenon makes it interesting to study. There are however at least two other reasons why a study of fund advertising is important. First, there is a trend towards investor autonomy around the world. Many companies move away from defined benefits plans, and to defined contribution (DC) savings plans, like 401(k)-plans in the U.S. For example, Poterba, Venti and Wise (2001) report that about 85\% of the private pension plan contributions in the U.S. are to plans in which retirement savers themselves choose how to invest their money. The trend towards investor autonomy is apparent also in the current world-wide debates over whether to privatize public pension systems, such as Social Security in the U.S. As more and more people are given the responsibility to act as their own money managers, an increasing number of them will be exposed to fund advertising when they elect investments in their retirement savings accounts.

Second, there is also a trend towards an expansion in the number of investment alternatives available to retirement savers and other individual investors. For example, about a decade ago, investors in the world's largest DC-plan had only two choices, a bond fund (TIAA) 
and a stock fund (CREF). Today, most plans offer more than one provider of funds and dozens, if not hundreds, of funds from which to choose. And in the U.S. mutual fund industry as a whole, statistics from the Investment Company Institute show that people have 8,256 choices, i.e. there are more funds than stocks to pick from. Clearly, the potential role for fund advertising is much more significant today, when the number of investment alternatives is in the thousands, than when people had only a limited number of choices.

So how then may fund advertising affect people's portfolio choices? Economic theory and experimental evidence suggest several potential links between advertising and portfolio choices. First, advertising may provide direct information about characteristics of a product or brand that are relevant to a consumer. Fund advertising may for example provide information about the "price" of funds, i.e. fund fees. This would reduce the search costs in the mutual fund industry. Second, the level of "uninformative" advertising may be used as a signal for the initially unobservable quality of a product. If fund managers with certain unobservable ability and talents are better than others, higher advertising expenditures may be used to signal higher subsequent returns. Finally, experimental evidence has shown that mere repeated exposure to a stimulus enhances people's attitude towards it. Thus, mere exposure to an advertisement for a fund may enhance people's attitude towards the advertising fund or fund complex, even if the advertisements provide no information at all. These hypotheses regarding a possible link between advertising and portfolio choice motivates the formal empirical work pursued in this paper.

A serious obstacle constraining any empirical attempt to study whether fund advertising affects portfolio choices is the lack of data. It is very difficult to obtain detailed and comprehensive data on people's portfolio choices as well as data on fund advertising. While 
extremely important in turning financial economists' attention to fund advertising, the paper by Jain and Wu (2000) illustrates this problem: they use a very small sample (294 ads) and, as an explanatory variable, a dummy that is one if a fund had an ad in two specialized magazines (Barron’s or Money magazine) during the period 1994-1996, and zero otherwise. ${ }^{1}$ I deal with the data availability problems by examining data generated by a unique event: the year 2000 launch of a privatized social security system involving individual savings accounts in Sweden. I combine two datasets in my analysis, one on people's portfolio choices, and one on fund advertising. The dataset on people's portfolio choices comes from the government authority that administrates the system, and consists of the portfolio choices for 4.4 million Swedish workers, in total allocating $\$ 5.6$ billion dollars. The dataset on fund advertising comes from a Swedish marketing research company's proprietary database, and contains detailed information on the advertising campaigns by the 455 participating mutual funds, in total 94.4 million dollars worth of ad expenditures, and close to 50,000 different fund advertisements and commercials.

I report four main results regarding the above outlined hypotheses regarding a link between advertising and portfolio choices. First, content analysis reveals that a very small portion of ads can be construed as directly informative about characteristics relevant for rational mutual fund investors, such as funds' expense ratios. Second, higher levels of advertising expenditures do not appear to signal ex ante higher unobservable fund manager quality, at least not in the short run (here defined as three years of post-advertising excess returns data). If anything, fund advertising in linked to underperformance. Third, fund advertising affects people's portfolio choices, even when advertising does not contain any information. Finally, I show that fund advertising has significant economic effects: it steers people to portfolios with

\footnotetext{
${ }^{1}$ Jain and Wu report that funds with an ad in Barron's or Money magazine significantly underperform in a one-year post-ad period compared to benchmarks such as the S\&P 500 index. Their dataset does not allow them to test whether the dollar amount of advertising expenditures signals higher quality.
} 
lower returns (through higher fees) and higher risk (through a higher exposure to stocks, more active fund management, more hot market segments, and much more local concentration). My results have several important implications for a welfare analysis of fund advertising and portfolio choices, asset pricing models, and mutual fund industry policy making, and may serve as a starting point for wider and more formal analysis of the effects of advertising, marketing, and persuasion in financial markets.

The rest of the paper is organized as follows. Section 2 reviews economic theory and experimental evidence suggesting that fund advertising may affect people’s portfolio choices, and explains how such arguments may be tested empirically. Section 3 describes the event and the data. Section 4 reports the results and performs robustness checks. Section 5 estimates the economic effects of fund advertising on portfolio returns and risk. Section 6 concludes the paper, and suggests some extensions for future research.

\section{Advertising and portfolio choice: Theory}

\subsection{Advertising as direct information}

An early literature on the economics of advertising started with a series of important papers by Nelson (1970, Nelson (1974). He emphasizes advertising's information function. ${ }^{2}$ The most obvious procedure available to a rational consumer in obtaining information about the quality or price of a product or brand is costly search. For "search qualities" (i.e., qualities of a product that can be determined by inspection prior to the purchase of a brand, such as the style of a dress or a suit), advertising may provide direct information about product characteristics that

\footnotetext{
${ }^{2}$ See also Stigler (1961), who constructs a model of optimal search behavior, in which advertising reduces search costs, and thus price dispersion.
} 
are relevant to a consumer. By so doing, advertising reduces search costs, which will make consumers' better off.

When applying Nelson's theory to fund advertising and portfolio choice, an important question to ask is: what attributes of mutual funds may advertising provide direct information about? Since there is little evidence that funds that have outperformed in the past will continue to do so, ${ }^{3}$ fund advertising about past returns does not appear directly informative. However, because there is evidence that lower-fee funds outperform other funds net of fees (e.g., Elton, Gruber, Das and Hlavka (1993)), advertising may provide information about funds' charges and expense ratios. Hortacsu and Syverson (2004) show that the dispersion in fees among U.S. index funds (a perfectly homogenous group of funds) is very large: the fee range stretches from below 10 to over 250 basis points per year. By providing information about fund fees, advertising has the potential of reducing search costs for investors in the mutual fund industry.

I test the direct information hypothesis by systematically investigating the message of fund advertising using observational research methods than have previously been used by marketing researchers and also by political science researchers to identify the content/message of election campaign ads.

\subsection{Advertising as a signal of quality}

Much advertising appears to convey no or little direct credible information about product characteristics. Motivated by this observation, Kihlstrom and Riordan (1984) and Milgrom and Roberts (1986) develop models in which advertising can still be informative, but indirectly so, if

\footnotetext{
${ }^{3}$ Hendricks, Patel and Zeckhauser (1993) and Brown and Goetzmann (1995) find evidence of persistence in fund performance over relatively short horizons (one to three years). Grinblatt and Titman (1992) suggest that a fund's current performance can predict performance 5 to 10 years into the future. By contrast, Carhart (1997) suggests that most of the after-expenses performance persistence in his sample can be attributed to the one-year momentum effect of Jegadeesh and Titman (1993) in the underlying stock returns, with much of the remaining persistence attributable to the worst-performing funds.
} 
there exist market mechanisms that produce a positive relationship between product quality and advertising expenditures. In this case, consumers can correctly infer initially unobservable quality from observable advertising. That is, advertising may signal quality.

Chevalier and Ellison (1999) study fund manager characteristics and performance for a large sample of mutual funds in the U.S. They document that some managers, in particular those who attended higher-SAT undergraduate institutions, have systematically higher risk-adjusted excess returns. Their finding that managers with certain observable characteristics outperform others raises the possibility that managers with certain (to investors and the econometrician) unobservable ability and talents are better than others. Under some conditions, such as learning about quality through repeat business, fund managers of ex ante higher quality may use higher fund advertising expenditures to signal higher quality. ${ }^{4}$

I test the signaling hypothesis by examining whether funds with higher advertising expenditures are associated with higher post-advertising excess returns.

\subsection{Advertising as mere exposure}

Behavioral models reject the idea that advertising only provides information. Instead, individuals’ choices are determined by both cognition and emotions (Kahneman, Slovic and Tversky (1982)). Two concepts from the theory of “mere exposure” (Zajonc (1968)) have been particularly actively explored in marketing practices and research: attitudes can change also

\footnotetext{
${ }^{4}$ Let me elaborate on the intuition behind the conditions that must be in place between funds and their investors for there to exist a separating equilibrium. Advertising can signal quality only if higher-quality funds find it profitable to invest in relatively more advertising than do lower-quality funds, and conversely. If advertising costs are the same for all funds, then the return to advertising must be greater for higher-quality funds. The greater returns may e.g. be learning through repeat business. While it is optimal for higher-quality funds to initially spend a lot on advertising (because of the repeat business that it will generate when people realize that this is a higher-quality fund), it is not the case for lower-quality funds, because they will not be able to recoup their initial advertising expenditures as people will realize that they are of lower-quality and not give them any repeat business.
} 
without cognition; mere exposure makes attitudes more favorable. ${ }^{5}$ According to this theory, people are more likely to buy an advertised product as opposed to one that is not because the advertised product is more familiar to them. While Zajonc's conclusion that “mere repeated exposure of the individual to a stimulus is a sufficient condition for the enhancement of his attitude toward it” (p.1) was a controversial idea in the 1960s, Bornstein (1989) has shown, through his meta-analysis of over 200 experiments, that mere exposure effects can be found in a lot of events and be replicated commonly.

In the area of mutual funds the theory of mere exposure means that advertising of a fund may enhance people's attitude towards the fund or the fund complex, although the fund advertising provides no information at all. That is, the choice of a particular fund or portfolio by an investor or retirement saver may not necessarily be the result of rational conscious information-processing by the investor. Instead, familiarity and awareness, created through fund advertising, may arise certain key positive emotions in investors, which make their attitudes towards a fund more favorable. ${ }^{6}$

My strategy for testing the mere exposure hypothesis is straightforward. I start by examining the extent to which fund ads provide direct information or signal higher postadvertising excess returns. In instances where they do not, but fund advertising is still found to

\footnotetext{
${ }^{5}$ In Zajonc's classical experiment, subjects were exposed to 12 stimuli of Turkish words, Chinese characters or yearbook photographs for two seconds with six frequencies $(0,1,2,5,10$, and 25$)$. The instructions informed subjects that the study deals with "pronouncing foreign words," "learning a foreign language" and "visual memory," and subjects were asked to rate how "good" they thought that the meaning of each word and character was, and how much they liked the person pictured in each photograph. While no information, only exposure, was communicated, subjects' attitudes toward a particular word, character or photograph were shown to be significantly more positive as the frequency of their stimuli was increased.

${ }^{6}$ Some recent financial research suggests that people like the familiar, also in financial markets contexts. Huberman (2001) shows a Regional Bell Operating Company's shareholders tend to hold its shares rather than other RBOCs' equity, and argues that this is evidence of people investing in the familiar. Benartzi (2001) reports that roughly a third of assets in large retirement savings plans are in company stock and that those who are "very familiar" with their employing firm show a somewhat higher correlation between past and predicted future own-company stock returns.
} 
affect people's portfolio choices, the theory of mere exposure provides an alternative that cannot easily be ruled out.

\section{The event and data}

\subsection{The event: Sweden's social security reform}

In 2000, Sweden launched a partial privatization of its public pension system, the “Premium Pension”. In the reformed system, 2.5\% of workers’ annual earnings are contributed to so-called individual savings accounts. In summary, the privatization plan had the following six important features: ${ }^{7}$

1. Participants were allowed to form their own portfolios by selecting from an approved list of Swedish and international mutual funds, some of which specialize in only one type of asset, such as IT-funds, while others, life-cycle funds, are designed with retirement savings in mind.

2. One fund, Sjunde AP-Fonden's Premiesparfonden, was chosen to be the default fund for anyone who does not make an active portfolio choice.

3. Any fund meeting standard fiduciary standards was allowed to enter the system.

4. Information about the funds, including fees, past performance, etc., was provided in the Fund Catalogue to all participants prior to the initial elections.

5. Balances and future contributions can be changed at any time, but unless some action is taken, the initial allocation determines all future contribution flows.

6. Funds, except the default fund, were allowed to advertise.

\footnotetext{
${ }^{7}$ See Cronqvist and Thaler (2004) for a more extensive discussion of design choices in privatized social security systems in general, as well as the specific design choices that Sweden decided to go with.
} 
With the above features, the Swedish "experiment” provides a unique opportunity to examine whether fund advertising affects people's portfolio choices. First, real dollars were at stake for millions of retirement savers. Second, market entry determined the extensive menu of funds that participants could choose from. Finally, different funds chose very different levels of advertising expenditures, from no advertising at all to spending millions on advertising.

\subsection{Data sources and summary statistics}

This paper combines two very detailed datasets from the event, one on people's portfolio choices, and one on fund advertising. The dataset on people's portfolio choices comes from the Premium Pension Authority (Premiepensionsmyndigheten, or PPM), the government authority that administrates the individual savings accounts in the reformed pension system. Panel A of Table 1 shows that as many as 4.4 million workers allocated a total of 5.6 billion dollars. Initially, the size of the accounts ranged from $\$ 10$ to $\$ 2,639$. The mean was 1,265 dollars. The average amount may seem small. However, as most people exhibit a status quo or default bias in their retirement savings accounts (e.g., Samuelson and Zeckhauser (1988) and Madrian and Shea (2001)), the present value of a worker's future contribution flows is many times greater than these "year 0" numbers alone suggest (in particular for younger people for whom the new system is more critical).

The dataset on fund advertising comes from a Swedish marketing research company, MarketWatch. I have manually collected and compiled a large dataset of fund advertisements and commercials by searching for all the funds and fund complexes that were part of the reformed pension system in the company's proprietary database. This database contains practically all advertisements and commercials that appear in Swedish print and broadcast media: 
- Advertisements that appear in more than 250 newspapers, and in the popular press and professional journals, as well as outdoor ads on billboards and busses, and even in subway stations, etc.

- Commercials from all the major television and radio networks, and also those appearing in the largest movie theaters.

Panel B shows that during the two years prior to the initial portfolio choices, funds spent a total of $\$ 94.4$ million on advertising. The dataset contains 23,604 advertisements ( $47.2 \%$ of the total expenditures), ranging in size and scope from small local newspaper ads to large billboard-type ads, such as one covering the exterior of a 34 story office building in downtown Stockholm. There are also 20,647 commercials (52.8\% of the total expenditures), ranging from two-second weather sponsorship spots to an eight and a half minute long "infomercial" on how to choose (the fund complex's) mutual funds. Advertisements in print media and television commercials account for about 90 percent of all the ad expenditures. Finally, Panel C shows summary statistics for the funds in the list that people could choose from.

\section{Results}

\subsection{Descriptive evidence}

Before presenting the main results and testing the hypotheses, it is useful to consider some simple descriptive evidence. First, I present evidence on "advertising recall” from a large survey, an exit poll of 1,083 retirement savers (selected to be representative of the population), implemented by a leading phone survey company (Sifo) during the days following people’s initial portfolio choices. Figure 1 reports fund advertising recall ratios for four categories of fund advertising. We see e.g. that as many as $75 \%$ of the investors recalled seeing some advertisement in a newspaper or other print media, and $86 \%$ recalled seeing some TV- 
commercial. Thus, most investors were exposed to at least some fund advertising before choosing their initial portfolios.

Second, I report evidence on the effects of the aggregate level of fund advertising. Figure 2 shows total fund advertising and the proportion of active portfolio choices each year during the period 2000-2005. As can be seen, aggregate advertising was much greater in year 2000, simply because as many as 4.4 million workers made their first elections (and $\$ 5.6$ billion were at stake for fund managers), than in e.g. year 2005, when only 116,000 new workers joined the plan (and only \$17.4 million were at stake). The observation that the fraction of active choices is much higher in years with more advertising suggests a link between fund advertising and people’s portfolio choices.

Finally, I report evidence on whether funds that spent more on fund advertising were able to attract more of investors' money. Figure 3 plots the dollar allocation to a fund as a function of the fund's level of expenditures on fund advertising prior to people's initial portfolio choices. The correlation is 0.544 and statistically significant $(p$-value $=0.000)$. Of course, this evidence does not say anything about why fund advertising affects people's portfolio choices, i.e. whether it provides direct information, signals higher quality, or affects people through mere exposure. Furthermore, this positive correlation is merely suggestive of an association between advertising and portfolio choices because advertising may be proxying for some other important fund characteristics affecting people's portfolio choices.

\subsection{Evidence on advertising as direct information}

I test the direct information hypothesis by systematically investigating the information content of the fund advertising. To do so, I implement Resnik and Stern (1977) content analysis method for identifying messages in ads. They classify "cues” in ads into the following 14 
categories: price, performance, independent research, company research, availability, components or contents, new ideas, quality, special offers or promotions, guarantee, nutrition, packaging or shape, safety, and taste. Several of them, like nutrition or taste, are obviously not applicable to the mutual fund industry.

To keep the analysis simple and tractable, I choose to classify cues in fund advertising into three broad categories:

1. Fee cue. A fund ad is considered to have a "price," i.e. fee, cue if it contains a reference to the fund's fees, charges, or expense ratios.

2. Performance cue. I aggregate Resnik and Stern's three cue categories performance, independent research and company research into one category as they, in the fund industry, are all related to past performance (returns). A fund ad has a performance cue if it contains the fund's return for some period (e.g., past year, 5 years or the fund's lifetime), Morningstar's star rating, other independent research company’s rankings, or any other return comparison, with e.g. an index or category, chosen by the advertising fund itself.

3. Other cue. These are ads that do not have a fee or performance cue.

Operationally, I have implemented the content analysis along these lines by combining information available in the content description field in MarketWatch's database as well as information from the National Library of Sweden, which by law is required to store, indefinitely, one copy of all Swedish published material for research purposes.

Table 2 contains examples of fee, performance, and other cues, and the Appendix provides one illustration for each advertising/cue category. The results of the content analysis deserve some comments, because this is the first attempt to systematically identify the message 
of fund advertising that retirement savers and other individual investors are exposed to. First, as can be seen in the table, fee advertising contains a message such as e.g. "If the price of milk goes up. Does it then taste better?” However, only $9.8 \%$ of the fee advertising $(0.8 \%$ of all advertising) contains information that allows investors to actually compare the expense ratio of the advertised fund to that of other funds in the fund's category. An example of this observation is an ad stating "Compare our fees!" This is a fee ad in my sample, though it contained no information about the expense ratio of the advertised fund, nor of any of the fund's competitors' charges.

Second, performance ads emphasize Morningstar's stars or past returns, some over the past year, others over 5 years, yet others over the lifetime of the fund, supposedly depending on what frame shows the greatest performance advantage for the advertised fund. More importantly, performance ads tend to involve "hot segments" of the overall market portfolio, with high past raw returns. Since the Swedish social security reform took place in year 2000, it should not come as a surprise that as much as $96.9 \%$ of the performance advertising in my sample involved stock or mixed funds, in particular those tilted towards information technology stocks, a very hot market segment in year 2000.

Finally, the category other advertising involves a wide variety of different content. For example, one fund complex featured actor Harrison Ford in print ads, and also placed TVcommercials in the blocks of the Swedish television premiere of the movie Air Force One, starring Mr. Ford. As can be seen in the table, this is one of many examples of ads playing on different facets of the phenomenon of familiarity. Of course, associating a fund with something that investors are already familiar with may be very useful under the mere exposure hypothesis for fund advertising. The observation that funds tend to differentiate themselves by their 
advertising -- one fund uses Harrison Ford others something else -- is clearly very interesting, but it is beyond the scope of the present paper to evaluate the relative effectiveness of different fund advertising strategies.

Table 4 shows the proportions of advertising dollars that were spent on fee, performance, and other advertising, respectively. As we can see, only 7.9 percent of the advertising involves ads with a fee cue. By contrast, performance advertising accounts for as much as 30.0 percent, while the rest is advertising containing another cue. Consistent with much research on other, non-financial, advertising, we see that fund advertising in print media is relatively more informative about fund fees than commercials: $13.5 \%$ vs. $2.9 \%$ of the advertising dollars went to fee advertising. Taken together, the content analysis of fund advertising shows that there is little support for the direct information hypothesis (Nelson (1970, Nelson (1974)). A very small proportion of fund advertising can be construed as directly informative. Thus, fee advertising is not an important source of information for rational investors searching for funds with low charges.

\subsection{Evidence on advertising as a signal of quality}

Although such a small proportion of fund advertising appears to convey credible information about fund characteristics that should matter to investors, it can still be informative, but indirectly so. I test the signaling hypothesis by investigating whether funds with higher advertising expenditure levels prior to people’s initial portfolio choices are associated with higher post-advertising excess returns. In particular, I estimate the following cross-sectional regression model by OLS:

$$
A R_{i}[0, T]=\alpha+\beta A D E X_{i}+\gamma F M_{i}+\varepsilon_{i}
$$


where $i$ indexes funds, $A R_{i}[0, T]$ is a measure of the excess return in percent over a postadvertising time period of $T$ months, ${ }^{8} A D E X_{i}$ is a measure of the level of advertising expenditures prior to people's initial portfolio choices, $F M_{i}$ is a vector of observable fund and fund manager characteristics (including 29 dummy variables for fund categories), and $\varepsilon_{i}$ is an error term. The estimated coefficient of interest is $\beta$. The signaling hypothesis predicts that $\beta$ is strictly positive and significantly different from zero. The standard errors are corrected for clustering of the observations at the fund category level.

To start with, I examine the 12-month post-advertising period from 11/1/2000 to 10/31/2001. This horizon gives me much fewer data points for the estimation than I would prefer, but I want to avoid longer periods because of the possibility of a fund's manager or other important fund characteristics changing over time. I check the robustness of this choice of horizon below. Initially, I define excess returns as simple excess returns, i.e. a fund’s annual return minus the average annual return of all the funds in the fund's own Morningstar category. For my purposes, this is a conservative benchmark because mutual funds as group tend to underperform broad benchmarks. Thus, it should be relatively easy for the advertising fund to beat a more narrowly defined benchmark. I check the robustness to this particular choice of benchmark below.

The regression results are reported in Table 5. In column 1, as a measure of the level of fund advertising, I use total fund adverting expenditures in dollars. I include a squared term to pick up possible nonlinearities in the relationship. As can be seen, I find no evidence of a significant positive relation between fund advertising and post-advertising excess returns. The

\footnotetext{
${ }^{8}$ In this section, I examine gross returns. That is, I do not net out fees from returns because I conjecture that funds with higher advertising expenses have higher subsequent gross excess returns. In section 5, I then carefully analyze the link between advertising and funds' expense ratios.
} 
estimated coefficient on fund advertising ( $\beta)$ is negative (-0.0051) and decreasing (because the estimated coefficient on the squared term is positive), but statistically insignificant $(t=-0.59$ ). The point estimates means that a one-standard-deviation increase in total advertising is associated with $\$ 226$ thousand $\times-0.0051=-1.16$ percent lower excess returns per year. Column 2 drops the 29 fund category dummies, showing that the dummies, not fund advertising, were driving the explanatory power (measured by an adjusted $\mathrm{R}^{2}$ of $26.0 \%$ ) in the first column. Put differently, little of the post-advertising excess returns dispersion is predicted by fund advertising. In column 3, I add the interaction term Fund advertising $\times$ Quartile 4 advertising, because it is possible that an extreme level of advertising expenditures is required to signal higher quality. As can be seen, there is no such evidence, however.

In column 4, I constrain my tests to fund advertising with a performance cue. Recall that almost a third (30.0\%) of the advertising expenditure in my sample is performance advertising. Therefore, one possibility is that the fund managers who have outperformed others in the past and know that this is due to their unobservable ability (as opposed to chance) are the ones who use performance advertising as a signal. That could potentially explain the enormous emphasis on past returns in fund advertising. However, the negative (-0.0398) and almost statistically significant $(p$-value $=0.107)$ coefficient estimate on performance advertising is inconsistent with such an explanation. That is, my results are inconsistent with performance advertising signaling higher subsequent excess returns for a fund.

Table 6 checks the robustness of the above results regarding the signaling hypothesis and examines specific contexts where signaling effects should be most likely to appear. A first concern is that the use of simple excess returns may not be an appropriate method for adjusting returns for systematic risk. As an alternative, I therefore regress each mutual fund's monthly 
returns minus the risk-free rate on the monthly return of the fund's comparable Morningstar index minus the risk-free rate. I then use the intercepts of such regressions as measures of excess returns when estimating equation (1). Column 1 presents the results for a 12-month postadvertising period. The results are even weaker with this benchmark: the coefficient estimate drops from -0.0051 to -0.0023 . Column 2 reports the results for a 36-month post-advertising period because it may provide less noisy excess returns estimates. However, the estimated coefficient is even more negative compared to using the 12-month period.

A related concern is fund manager turnover. In the first three years 31 fund managers quit or were replaced in my sample. Fund advertising may only signal higher quality when the manager of the fund at the time of the fund advertising actually remains with the fund over a sufficiently long period. In column 3, I therefore constrain the analysis to managers who did not turn over during a 36-month post-advertising period. However, as can be seen, the effect of fund advertising is qualitatively similar when restricting the analysis to fund managers who did not turn over.

Another possibility is that fund advertising is used as a signal only by fund managers who do not appear to have superior skills based on observable characteristics, such as those with no or little experience from the mutual fund industry. I therefore interact fund advertising with proxies for lack of observable ability, such as being in the first (lowest) quartile in terms of years of managerial experience in the fund industry, being in the first quartile of managerial tenure length, or not having an MBA. However, the coefficient estimates on the interaction terms in column 4 are all negative and individually as well as jointly not different from zero ( $F$-value of Wald-test $=0.26$ ). That is, there is no evidence that fund advertising is used as a signal by those who do not appear to have superior skills based on observable characteristics. 
Theory also suggests that fund advertising may be more useful as a signal when the asymmetric information about a fund manager's ability is particularly high. In column 5, I add the interaction term Fund advertising $\times$ New fund because a newly started fund is likely subject to more information asymmetries. However, there is no evidence that fund advertising is used as a signal by better new funds. Another proxy for asymmetric information is the number of articles about a fund in media. Little media attention likely means more information asymmetries. In column 6, I interact fund advertising with a dummy that is one if the fund is in the first (lowest) quartile of the number of newspaper articles. There is no evidence that fund advertising is used as a signal by better funds with little media attention. An alternative measure of asymmetric information is whether the fund is part of a foreign fund complex, which local investors presumably have less information about. In column 7, I include the interaction term Fund advertising $\times$ Foreign fund. However, I find no evidence that fund advertising is used as a signal by better foreign funds.

Finally, ability and talent may play a particularly useful role when managing funds with specialized assets. As a result, fund advertising may be used by fund managers with superior skills who are managing specialized assets. In column 8, I therefore interact fund advertising with a dummy that is 1 if the fund is a pharmaceutical fund ( 7 funds in my sample), an IT and telecom fund (18 funds) or an emerging markets fund (21 funds). As can be seen, there is no evidence that fund advertising is not used as a signal of higher subsequent excess returns even among funds managing very specialized assets.

Taken together, I find no support for a signaling hypothesis (Kihlstrom and Riordan (1984) and Milgrom and Roberts (1986)) in the mutual fund industry. If anything, the signs of the estimated coefficients suggest a negative relation between fund advertising, especially 
performance advertising, and post-advertising excess returns. There are at least two reactions that one can have to this finding. One view is that because such a short period time is available for estimating excess returns, little can reliably be said about the cross-sectional differences in funds' returns. So if managerial talent reveals itself in the data only over the long run, I am simply unable to detect it in the sample that I investigate. Because a fund's manager and other important fund characteristics change over time, it will however be a challenging task to test the signaling hypothesis even with more post-advertising returns data readily available.

Another view is that fund advertising can not be used as a signal of quality in the mutual fund industry, not even in the long run. The reason is that there exist no market mechanisms that produce a positive relationship between the quality of a fund and advertising expenditures. One possible mechanism is learning about quality through repeat business. However, in retirement savings accounts, people are known to exhibit a status quo bias. For example, Samuelson and Zeckhauser (1988) found that the median TIAA-CREF plan participant made no changes to his or her account over the working lifetime (see also Madrian and Shea (2001)). In the reformed social security system in Sweden only 2-3\% made any changes to their initial portfolios in the first three years. Because of this inertia, there is no market mechanism in place which ensures that low quality funds and fund managers that mimic high quality ones by advertising are penalized through no repeat business by mutual fund investors.

\subsection{Evidence on advertising as mere exposure}

So far my analysis suggests that fund advertising provides little information, directly and indirectly. In this section, I ask: does fund advertising still affect people’s portfolio choices? In particular, I estimate the following cross-sectional regression model by OLS: 


$$
\log A_{i}=\alpha+\beta A D E X_{i}+\gamma F M_{i}+\varepsilon_{i}
$$

where $i$ indexes funds, $\log A_{i}$ is the natural $\log$ of the dollar allocation to a fund, $A D E X_{i}$ is a measure of the level of advertising expenditures prior to the event, $F M_{i}$ is a vector of observable fund and fund manager characteristics, and $\varepsilon_{i}$ is an error term. The standard errors are corrected for clustering of the observations at the fund category level.

The regression results are reported in Table 6. As can be seen in column 1, there appears to be a positive and statistically significant link between fund advertising and dollar allocations to funds in the cross-section of funds. In column 2, I add a squared term, which indicates that the marginal effect of advertising is decreasing in fund advertising. One potential explanation for the association between fund advertising and fund allocations is simply that funds that advertise more also differ along other dimensions. In column 3, I therefore include 29 fund category dummies to absorb unobservable fixed fund category effects in advertising. As can be seen, the effect of fund advertising is reduced by as much as 30 percent compared to column 1 , although it is still statistically significant at all significance levels $(t$-statistic $=5.42)$.

In the remainder of the table, I control for observable fund characteristics. In column 4, I add a dummy for local (i.e., Swedish) funds. Consistent with local funds advertising more and consistent with people having a strong preference for local funds the estimated coefficient on fund advertising decreases and the coefficient on the dummy for Swedish funds is positive and statistically significant. Column 5 controls separately for the location of a fund and the location of the fund's assets. ${ }^{9}$ The results are qualitatively similar compared to simply using a dummy for local funds. In column 6, I include fund size. While people prefer larger funds, including a

\footnotetext{
${ }^{9}$ The evidence that people prefer local funds is not surprising given the evidence on a "home bias" in stock portfolios (e.g., French and Poterba (1991) and Coval and Moskowitz (1999)).
} 
proxy for fund size does not change the effect of fund advertising. Column 7 controls for preevent market shares in the fund, retail banking, and retail insurance industries, respectively. As can be seen, banks and insurance companies with large pre-event market shares were able to attract more money. Again, the effect of fund advertising is unaffected. Column 8 includes news articles about the fund in media. Although the estimated coefficient on news articles is significant, the inclusion does not impact the effect of fund advertising.

In column 9, I control for past performance over the past 12 months (the results are robust to considering other periods, such as 36 months). I use raw returns as a measure of past performance because these figures where available to investors in the Fund Catalogue. For the subset of funds that are newly started, I define past performance to be zero and then include a dummy variable that is 1 if the fund is new, and 0 otherwise. As can be seen, people allocate more of their money to funds with higher raw returns. This result is in line with a larger literature documenting that mutual fund investors allocate a disproportionate amounts of money to funds that performed very well in the prior period (e.g., Sirri and Tufano (1998)). More importantly for my analysis, including past performance does not change the effect of fund advertising. Finally, I include all the control variables at the same time in column 10 . While including all these controls reduces the effect of fund advertising, it is still significant at the $1 \%$ level.

The last column of the table reports the effect on the dollar allocation to funds, in percent, of changing each continuous (dummy) variable one standard deviation (from 0 to 1 ). As can be seen, the effect of fund advertising is economically significant, and at least as large as the effect of e.g. size (assets under management), media attention, and past performance, though not as large as the effect of a fund complex being local (home bias). The estimated effect of fund 
advertising means that a one-standard-deviation increase in fund advertising is associated with about 1.3 percent higher dollar allocation to a fund. A back-of-the-envelope calculation of the overall returns to advertising can also be computed. Total advertising expenditures were about $\$ 94.4$ million. However, the payoff is not received immediately, but instead as a stream of fee payments over many years. In year 2000, $\$ 5.6$ billion was allocated to the mutual funds. The average fee was about 97 basis points, implying that fund managers get about $\$ 54.3$ million from fees. This money should of course pay for more than advertising expenditures. Still, since people tend not to rebalance their retirement savings accounts, these figures suggest that the cumulative return on investment (ROI) to fund advertising can be significant.

One important concern is that the level of fund advertising is endogenously determined across mutual funds. In the above analysis, I have already taken several measures to attempt to deal with this potential problem. First, I control for unobservable fixed fund category effects that differ across the 29 different fund categories. For example, stock and IT-funds advertised more than other fund categories in year 2000. As we could see, including fund category dummies significantly reduced the effect of fund advertising. Second, I employ White (1980) standard errors adjusted for clustering of the observations at the fund-category-level to account for the presence of cross sectional correlations in the data. Finally, I control for observable fund characteristics that differ across funds, such as whether the fund is Swedish or not. As could also be seen, this reduced the effect of fund advertising by about 50 percent. However, the effect of advertising was still shown to be positive and statistically significant, even after adding this extensive set of control variables.

In Table 8, I further address endogeneity concerns by attempting to instrument for fund advertising. A measure of the relative costliness of fund advertising across funds would be an 
ideal instrument as it should be correlated with advertising (it may be less costly to advertise for a fund that is part of say a TV-conglomerate) but not directly correlated with fund allocations. Unfortunately it is difficult to measure the relative costliness of fund advertising with any precision in my sample. I propose lagged advertising as a possible instrument for fund advertising. Many would probably agree that lots of fund advertising in the past can be interpreted as relatively low costliness of advertising for a fund (at least at the time). Indeed, the correlation between fund advertising and lagged fund advertising in my sample is 0.536 , and the estimated coefficient on lagged advertising in the first stage of the 2SLS (see column 1) is statistically significant $(t$-statistic $=5.78)$.

Because of potential persistent branding effects of fund advertising it is however debatable whether lagged fund advertising is not directly correlated with contemporaneous fund choices. One argument for a low correlation is that mere exposure effects decay rapidly over time. Indeed, a phone survey by Sifo involving 1,000 Swedish retirement savers undertaken in March of 2001 revealed that as many as 73 percent did not recall what funds they chose six months earlier. This is at least suggestive of a rapid decay of mere exposure effects and advertising recall ratios in the mutual fund industry. Columns 2 and 3 show that the effect of advertising is in fact stronger when instrumenting for advertising using lagged advertising, suggesting that funds with "excess" advertising at the event attracted disproportionate amounts of money. Taken together, these findings make it is unlikely that endogeneity of fund advertising is a major explanation for my results.

Table 8 investigates the effects of the two most common categories of fund advertising: performance advertising and advertising with an "other" cue. ${ }^{10}$ Column 1 shows that people

\footnotetext{
${ }^{10}$ In all columns of the table, I include the same set of control variables as in the last column of Tables 7 and 8. To make the table tractable, I do not report these estimated coefficients explicitly.
} 
allocate more money to funds with more performance advertising. Column 2 reports that people also allocate more money to funds with more advertising with another cue than a fee or performance cue. Column 3 includes performance advertising and fund advertising with an other cue, and also interacts performance advertising with past performance. There are several important results. First, performance advertising and past performance have, independently of each other, a similar effect on fund allocations. Second, for the same change in advertising expenditures, we see that performance advertising is about twice as effective in attracting money compared to fund advertising with an other cue. Finally, performance advertising is particularly effective for funds with high past raw returns. These results can explain the enormous emphasis on past returns in fund advertising: a fund that has e.g. a 5-star Morningstar rating would rationally choose to market this in its advertising rather than to communicate some other cue.

For space reasons, I shall summarize without directly reporting some robustness tests that I have performed. First, I reestimate all the basic models using various other measures of fund size, such as the number of employees; the results were unaffected. Second, I replicate all of the analysis for equity funds only; the results were unaffected. Third, I have included the fund's expense ratio and turnover as control variables; again, the results were not affected. Finally, I reestimate all regressions for the top-100 most popular funds (almost all of which were local funds); the results were generally stronger in spite of this drastic reduction in sample size.

\section{Estimating the effects of advertising on portfolio returns and risk}

Fund advertising has the potential of affecting the returns or the risk of an investor's portfolio, or possibly both. I start by estimating the effects of fund advertising on portfolio returns because they are more straightforward. First, it is noticeable that the signs of the estimated coefficients in section 4.3 (where I tested the signaling hypothesis) suggest a negative 
relation between fund advertising and post-advertising excess returns. Indeed, Jain and $\mathrm{Wu}$ (2000) report that the advertising equity mutual funds in their sample underperformed the S\&P index by as much as 7.88 percent per year (with a $t$-statistic of 11.46). Thus, my evidence and prior research suggest that funds that spend more on advertising may underperform other funds. As a result, choosing mutual funds based on their advertising can considerably reduce investors' wealth available for e.g. retirement.

Second, fund advertising may also have an effect on the fees that investors are willing to pay. Funds and fund complexes, like companies in so many other industries, want to avoid price competition (in this case "fee competition"). It has long been recognized in economics that one approach to doing so is product differentiation. And marketing research has revealed that such product differentiation may be on a "meaningless" attribute rather than one that is relevant, meaningful, and valuable to consumers (e.g., Carpenter, Glazer and Nakamoto (1994)). As a result, investors may be willing to pay higher fees for funds that advertise more, even if much of the advertising does not provide direct information.

In Table 9, I examine whether more fund advertising is linked to higher fees by regressing funds' fees on fund advertising. In particular, I estimate the following cross-sectional regression model by OLS:

$$
\mathrm{Fee}_{i}=\alpha+\beta A D E X_{i}+\gamma F M_{i}+\varepsilon_{i}
$$

where $i$ indexes funds, $\mathrm{Fee}_{i}$ is the fund's annual expense ratio in percent, $A D E X_{i}$ is a measure of the level of advertising expenditures prior to the event, $F M_{i}$ is a vector of observable fund and fund manager characteristics (including 29 dummy variables for fund categories), and $\varepsilon_{i}$ is an error term. The standard errors are corrected for clustering of the observations at the fund category level. Consistent with a product differentiation hypothesis, column 1 shows that funds 
that use more advertising are able to charge their investors significantly higher fees. All of the results of fund fees are stronger if restricting the analysis to Swedish funds only (unreported).

Advertising, even if it does not provide any direct information, may be used to grab people's attention and to encourage them to call a fund complex's toll-free phone number or to visit a fund's webpage. ${ }^{11}$ Therefore, the above results may simply reflect that advertising funds provide services to investors, such as financial advice, and that they are appropriately compensated for doing so through higher fees. In column 2, I therefore add the variables Log (Assets under management) and Log (Other employees) because larger funds, and especially fund complexes with many employees other than fund managers and fund analysts, may be more likely to provide such services to investors. While there is some evidence that funds that are part of fund complexes with more such employees charge higher fees, these proxies do not affect the link between fund fees and fund advertising. Perhaps a better proxy for service provision is whether the fund complex that a fund is part of has retail outlets (such as banks' or insurance companies’ branches). As can be seen in column 3, there is some evidence that funds with retail outlets are able to charge higher fees, but again the effect of fund advertising on funds' fees is unaffected. In column 4, I include all the proxies for services provision simultaneously, but the results are not affected.

The last column estimates the economic significance of the regression results. As we can see, the coefficient estimate in column 4 means that a one-standard-deviation increase in fund advertising is associated with about 50 basis points higher fees per year. If a retirement saver chooses mutual funds based on advertising and thus pays higher fees of this order of magnitude till he retires, what are then the effects on the wealth available for retirement? My calculations suggest that the investor will retire with 7.2 percent less wealth in his retirement savings account

\footnotetext{
${ }^{11}$ I thank Laura Starks for suggesting an analysis of funds’ service provisions and financial advice.
} 
if he is currently 50 years old and retires at the age of $65 .{ }^{12}$ For a young , say 20 years old, investor the effect is of course much larger: 20.2 percent less wealth is available. These types of back-of-the-envelope calculations show that fund advertising has the potential of steering people towards higher fee funds, and that this can accumulate over time to significant effects on wealth available for retirement.

In addition to significant effects on portfolio returns, fund advertising can also affect the risk that investors take on. Estimating the effects of fund advertising on portfolio risk is not as straightforward. One method is to construct what I dub an "advertising-induced portfolio" (“AIP” below) by investing in different funds in proportion to their levels of advertising expenditures, and then compare some risk characteristics of such a portfolio to some relevant alternative portfolio. In particular, I calculate a risk characteristic of the advertising-induced portfolio in the following way:

$$
R C_{A I P}=\rho_{i} R C_{i}
$$

where

$$
\rho_{i}=\frac{A D E X_{i}}{\sum_{i=1}^{455} A D E X_{i}}
$$

\footnotetext{
${ }^{12}$ Assume that a percentage fee $f$ is charged each year $t \in(0, T]$, where $T$ is the investor's investment horizon, on the beginning of the year market value of the fund, $V_{t}$. The fraction of the initial market value of the fund, $V_{0}$, to be paid the first year is $f$, leaving a fraction $(1-f)$ of $V_{0}$ to the investor. On this remaining fraction, another fraction $f$ is paid the second year, corresponding to a fraction $f(1-f)$ of $V_{0}$, leaving the investor with a fraction of $V_{0}$ not paid as a fee the first or second year of

$$
1-[f+f(1-f)]=(1-f)^{2} .
$$
}

Thus, the present value of the fees to be paid over the first two years is

$$
\left[1-(1-f)^{2}\right] V_{0} \text {. }
$$

It can be shown, following Ross (1978), that that the present value of the fees paid over $T$ years is

$$
\left[1-(1-f)^{T}\right] V_{0} \text {. }
$$


and where $i$ indexes funds, $R C_{i}$ is a risk characteristic, $A D E X_{i}$ is a measure of the level of advertising expenditures prior to the event.

Table 10 compares some risk characteristics of the AIP to the alternative of not actively choosing any portfolio at all, whereby a retirement saver's money would be automatically invested in the default fund. I report several economically significant differences between the two portfolios. First, although the allocation to equities in the default fund was quite high, the AIP is practically an all-equity portfolio with 98.9 percent in stocks. Second, only $0.4 \%$ of the money in the AIP were invested in index funds. Third, the AIP was tilted towards investments in hot market segments (which may potentially have been overvalued), with 60.5 percent of the money in high-tech and IT stocks. Finally, there is a substantially larger "home bias" in the AIP: 81.2 percent was invested in Swedish stocks. That is, the AIP has a higher exposure to stocks, more active fund management, more hot market segments, and much more local concentration. Comparing the two portfolios, it seems hard to make the case on an ex ante basis that the advertising-induced portfolio is a more optimal portfolio based on the risk an investor takes on than is the default fund. In sum, the above analysis shows that fund advertising steers investors to portfolios with lower returns and higher risk.

\section{Conclusion and Extensions}

In this paper, I have presented empirical evidence on the link between fund advertising and people’s portfolio choices. I have four main results. First, content analysis reveals that a very small portion of ads can be construed as directly informative about characteristics relevant for rational mutual fund investors, such as funds’ expense ratios. Second, higher levels of advertising expenditures do not appear to signal ex ante higher unobservable fund manager 
quality, at least not in the short run (here defined as three years of post-advertising excess returns data). If anything, fund advertising may be linked to underperformance. Third, fund advertising affects people's portfolio choices, even when advertising does not contain any information. Finally, fund advertising has significant economic effects: it steers people to portfolios with lower returns (through higher fees) and higher risk (through a higher exposure to stocks, more active fund management, more hot market segments, and much more local concentration).

These findings are not consistent with standard models in economics emphasizing advertising's information function. Nor are they consistent with arguments that advertising is a compliment to the advertised product (Becker and Murphy (1993)). Under this view, the same "favorable notice" would be equally effective for all funds. This is inconsistent with the enormous emphasis on content of non-informative advertising, which varies in the cross-section of mutual funds -- Harrison Ford for one fund, some entirely different favorable notice for some other fund. My results are more consistent with a model in which mere exposure to a fund through its advertising creates familiarity and thus affect with the fund. A next step in further understanding the link between advertising and portfolio choice is formal modeling of this relationship. Without such models, our understanding of the link will necessarily be vague. My evidence raises the possibility that fund advertising can have significant effects also on aggregate and individual stock prices. In standard asset pricing models, like the SharpeLintner CAPM, changes in the demand for stocks that are not driven by news have no effects on stock prices. By sharp contrast, if demand curves for stocks are downward sloping, shocks to demand caused by advertising can actually translate into economically significant effects on stock prices. During the period 2000-2005, on the days of the annual billion-dollar retirement savings flows following the Swedish social security reform, a broad stock market index in 
Sweden has outperformed the MSCI Europe index by as much as $1.77 \%$, on average. ${ }^{13}$ Since advertising was at least partly responsible for the demand shock to equities, especially IT-stocks, the evidence in the present paper suggests a link between fund advertising and stock prices.

This paper's results have implications for regulators and other policy makers, and for mutual fund industry incumbents. It is important to recognize that the objective of fund complexes is to sell fund shares to maximize profits for their shareholders, not to maximize retirement savers' pensions or investors' wealth, like the goal of pharmaceutical companies is to sell drugs, not maximize patients' health. The presence of agency problems in the money management industry has recently been recognized in finance research. Fund advertising adds another dimension to the problem. With advertising and other selling efforts, branded funds can charge investors significantly higher fees than the lowest-cost supplier in the industry. Because of similar agency problems, industries like the U.S. pharmaceutical industry with PhRMA's recent "Guiding Principles on Direct-to-Consumer Advertising,"14 have started to set their own standards on advertising to the general public, before regulators might have moved in to set the standards for them. The mutual fund industry may face similar issues in the future.

Several important questions remain unanswered. First, advertising is only one promotional tool in funds' total marketing mix. Do tools like selling efforts by financial planners and direct mailing have similar effects on people’s portfolio choices? Second, what can we learn from the time-series of fund advertising? One recent and important contribution is Mullainathan and Shleifer (2005), who show that the content of fund advertising is tilted toward what people have in mind at the moment, e.g. funds were more likely to use a performance cue after the market had gone up during the Internet bubble. The findings of this paper suggest that more

\footnotetext{
${ }^{13}$ In future research, I hope to explore the effects of flows of funds and stock prices in greater detail.

${ }^{14}$ For details, see the website of the Pharmaceutical Research and Manufacturers of America (PhRMA), http://www.phrma.org/.
} 
energy should be devoted to formal analysis of questions regarding the link between funds' advertising and marketing, or more generally persuasion efforts, and people’s portfolio choices. 


\section{References}

Becker, Gary S., and Kevin M. Murphy, 1993, A Simple Theory of Advertising as a Good or Bad, Quarterly Journal of Economics 108, 941-964.

Benartzi, Shlomo, 2001, Excessive Extrapolation and the Allocation of 401 (k) Accounts to Company Stock, Journal of Finance 56, 1747-1764.

Bornstein, Robert F., 1989, Exposure and affect: overview and meta-analysis of research, Psychological Bulletin 106, 265-289.

Brandstrader, J. R., 1996, Can mutual funds be sold like toilet tissue or toothpaste?, Barron's.

Brown, Stephen J., and William N. Goetzmann, 1995, Performance Persistence, Journal of Finance 50, 679-698.

Carhart, Mark M., 1997, On the persistence of mutual fund performance, Journal of Finance 52, 57-82.

Carpenter, Gregory S., Rashi Glazer, and Kent Nakamoto, 1994, Meaningful brands from meaningless differentiation: The dependence on irrelevant attributes, Journal of Marketing Research 31, 339-350.

Chevalier, Judith, and Glenn Ellison, 1999, Are Some Mutual Fund Managers Better Than Others? Cross-Sectional Patterns in Behavior and Performance, Journal of Finance 54, 875-99.

Coval, Joshua D., and Tobias J. Moskowitz, 1999, Home bias at home: Local equity preference in domestic portfolios, Journal of Finance 54, 2045-2073.

Cronqvist, Henrik, and Richard H. Thaler, 2004, Design Choices in Privatized Social-Security Systems: Learning from the Swedish Experience, American Economic Review 94, 42428.

Elton, Edwin J., Martin J. Gruber, Sanjiv Das, and Matthew Hlavka, 1993, Efficiency with costly information: A reinterpretation of evidence from managed portfolios, Review of Financial Studies 6, 1-22.

French, Kenneth R., and James M. Poterba, 1991, Investor diversification and international equity markets, American Economic Review 81, 222-226.

Grinblatt, Mark, and Sheridan Titman, 1992, The persistence in mutual fund performance, Journal of Finance 47, 1977-1984.

Hendricks, Darryl, Jay Patel, and Richard J. Zeckhauser, 1993, Hot hands in mutual funds: shortrun persistence of performance, 1974-1998, Journal of Finance 48, 93-130.

Hortacsu, Ali, and Chad Syverson, 2004, Product Differentiation, Search Costs, and Competition in the Mutual Fund Industry: A Case Study of S\&P 500 Index Funds, Quarterly Journal of Economics 119, 403-56.

Huberman, Gur, 2001, Familiarity breeds investment, Review of Financial Studies 14, 659-680.

Jain, Prem C., and Johanna Shuang Wu, 2000, Truth in mutual fund advertising: evidence on future performance and fund flows, Journal of Finance 55, 937-958.

Jegadeesh, Narasimhan, and Sheridan Titman, 1993, Returns to Buying Winners and Selling Losers: Implications for Stock Market Efficiency, Journal of Finance 48, 65-91.

Kahneman, Daniel, Paul Slovic, and Amos Tversky, 1982. Judgment under uncertainty: Heuristics and biases (Cambridge University Press, Cambridge ; New York).

Kihlstrom, Richard E., and Michael H. Riordan, 1984, Advertising as a Signal, Journal of Political Economy 92, 427-50.

Madrian, Brigitte C., and Dennis F. Shea, 2001, The power of suggestion: Inertia in 401(k) participation and savings behavior, Quarterly Journal of Economics 116, 1149-1525. 
Milgrom, Paul, and John Roberts, 1986, Price and advertising signals of product quality, Journal of Political Economy 94, 796-821.

Mullainathan, Sendhil, and Andrei Shleifer, 2005, Persuasion in Finance, Unpublished working paper, Harvard University.

Nelson, Phillip, 1970, Information and Consumer Behavior, Journal of Political Economy 78, 311-29.

Nelson, Phillip, 1974, Advertising as information, Journal of Political Economy 82, 729-754.

Poterba, James M., Steven F. Venti, and David A. Wise, 2001, Preretirement Cashouts and Foregone Retirement Saving: Implications for 401(k) Asset Accumulation, Themes in the economics of aging (University of Chicago Press, Chicago and London).

Resnik, Alan, and Bruce L. Stern, 1977, An analysis of information content in television advertising, Journal of Marketing 41, 50-53.

Ross, Steven A., 1978, A simple approach to the valuation of risky streams, Journal of Business $51,453-476$.

Samuelson, William, and Richard J. Zeckhauser, 1988, Status quo bias in decision making, Journal of Risk and Uncertainty 1, 7-59.

Sirri, Erik R., and Peter Tufano, 1998, Costly search and mutual fund flows, Journal of Finance 53, 1598-1622.

Stigler, George J., 1961, The economics of information, Journal of Political Economy 69, 213225.

White, H., 1980, A heteroskedasticity-consistent covariance matrix estimator and a direct test for heteroskedasticity, Econometrica 48, 817-838.

Zajonc, Robert B., 1968, Attitudinal effects of mere exposure, Journal of Personality and Social Psychology 9, 1-27. 


\section{Appendix 1 \\ Examples of fund advertising}

The appendix contains illustrations of fund advertising with a "price," i.e. fee, cue (Panel A), a performance cue (Panel B), and another cue (Panel C).

Panel A: Example of fund advertising with “price,” i.e. fee, cue

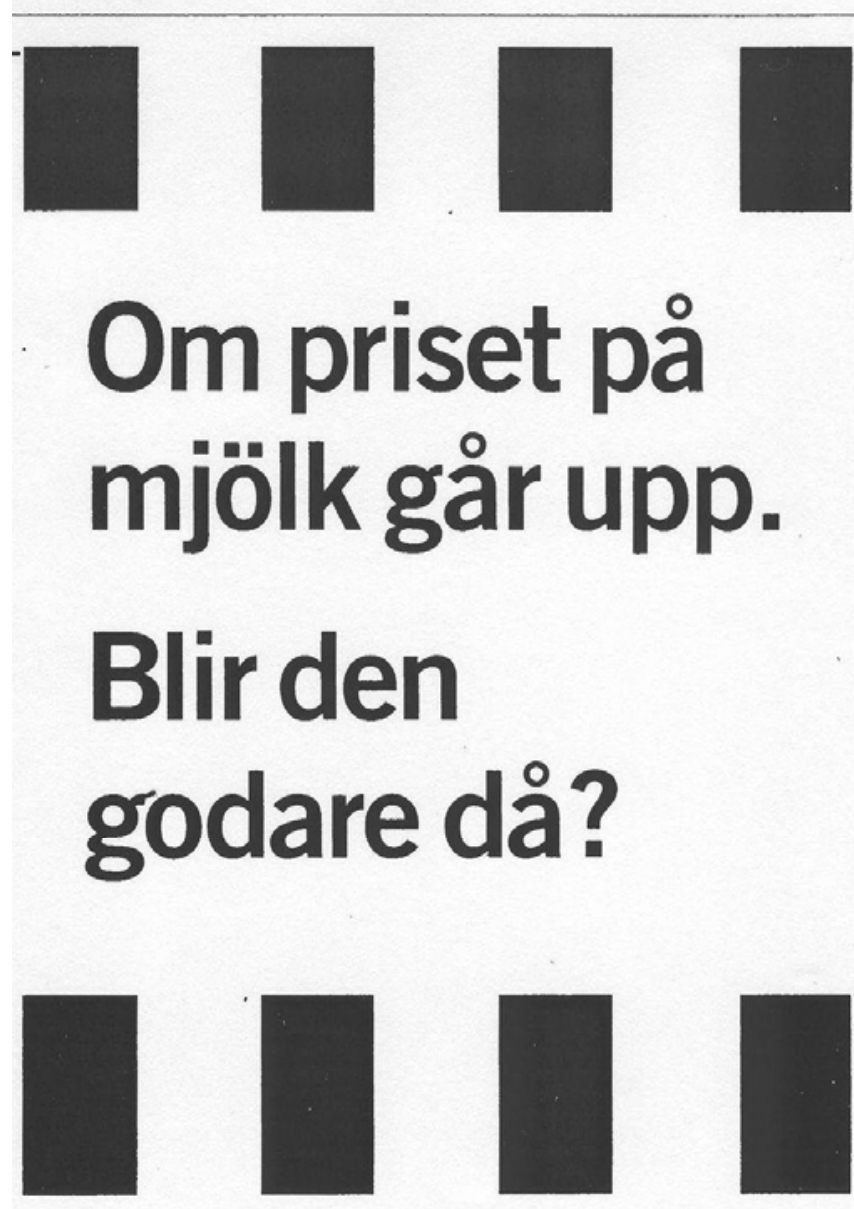

Högt pris och hog kvalitet ar inte alltid samma sak. Faktum är att vissa saker bara blir battre och bättre iu mindre de kostar. Så ar det for oss. Mảnga frågar sig hur dårt sparande kan kosta si lite. Svaret ar enkelt.

- Vi arbetar bara med pensioner - ingenting annat. Det gör att det blir enkelt och billigt att ta hand om dina pengar.

Dessutom ar vi en liten effektiv organisation, samlad under ett och samma tak.

Allt det här ger dig mer pengar nàr det ar dagss att ga i pension. Să enkelt är det.

Main text: "If the price of milk goes up. Does it then taste better?" 
Panel B: Example of fund advertising with performance cue

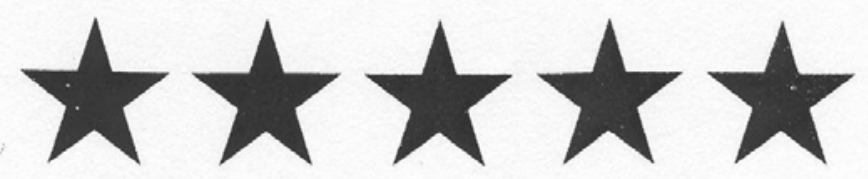

\section{SPARA FEMSTJÄRNIGT!}

Vår IT-fond, Sverigefond och Hjärt-Lungfond har fått högsta betyg; fem stjärnor av fem möjliga.

De har i konkurrens med alla andra svenska fonder tagit hem 3 av de 25 åtråvärda femstjärniga platserna på Fondstars* lista. Det betyder att fonderna har haft en mycket gynusam utveckling under de tre senaste åren.
Och en lönsam historia skvallrar om goda förutsättningar för framtiden.

* Fondstar becygsatter fonder som finns att kopa pá den svenska fondmarknaden. Bedömningen sker enligt en metodik utarbetad av det amerikanska fondinformationsföretaget Morningstar. Morningstar Rating ar en internationell standard for presentation av objektiv fondfakta. mww.fondstar.se

SalusAnsvar Ohman Fonder kan lika lite som andra fondbolag garantera framtida avkastning. Fullständig informationsbroschyr kan beställas fràn fondbolaget pá tel 020.525300 eller via www.salusansvarohman.se

Main text: “A five-star investment opportunity!” 
Panel C: Example of fund advertising with other cue

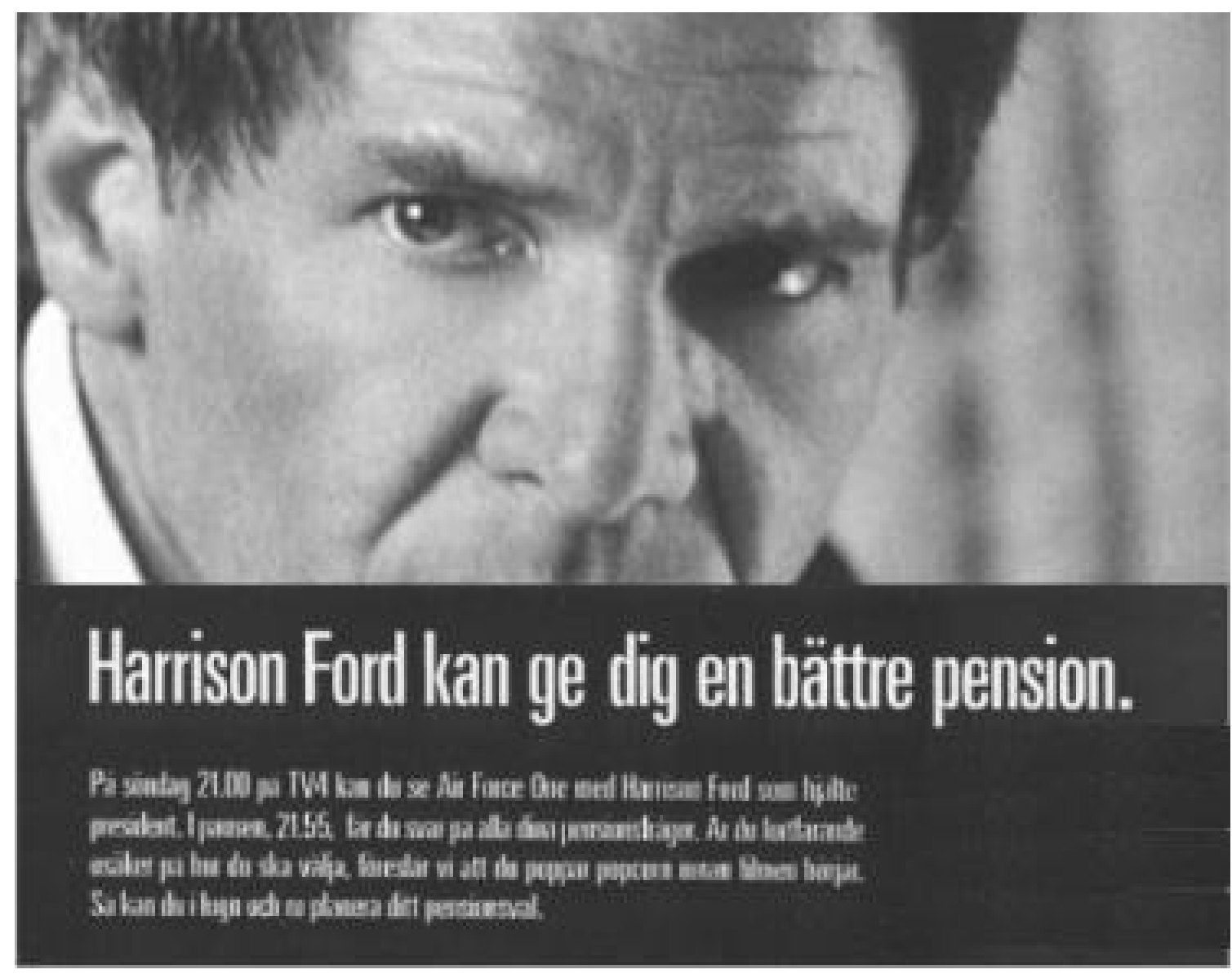

Main text: "Harrison Ford can give you a better pension.” 


\section{Table 1 \\ Summary statistics}

Panel A reports summary statistics for the dataset on people’s fund and portfolio choices at the year 2000 launch of a reformed social security system in Sweden. The data on portfolio choices come from the Premium Pension Authority. Panel B reports summary statistics for the dataset on fund advertising prior to the year 2000 launch of a reformed social security system in Sweden. The data on fund advertising come from MarketWatch. Advertisements are fund advertisements appearing in more than 250 newspapers, and in the popular press and professional journals, as well as outdoor ads on billboards and busses, and in subway stations, etc. Commercials are fund commercials from all the major television and radio networks, and those appearing in the largest movie theaters. Panel $\mathrm{C}$ reports summary statistics for the list of mutual funds that people could choose from. The data on fund characteristics are from Morningstar or have been hand-collected from funds' annual reports. Fund advertising is total fund advertising expenditures in thousands of dollars prior to the event. Fund manager experience is the number of years of managerial experience in the fund industry. Fund manager tenure is the fund manager's length of tenure with the fund (in years). Fund manager MBA is a dummy variable that is 1 if the manager has an MBA, and 0 otherwise. Specialized assets fund is a dummy variable that is 1 if the fund is a pharmaceutical fund, an IT and telecom fund, or an emerging markets fund, and 0 otherwise. Local fund complex is a dummy variable that is 1 if the fund complex that the fund is part of is registered in Sweden, and 0 otherwise. Distance to fund is the average flight time from Stockholm to the fund's headquarter in minutes (Swedish headquarters are defined to have zero distance). Distance to fund assets is market value weighted flight time from Stockholm to the fund's assets in minutes (Swedish assets are defined to have zero distance). Assets under management is total assets under the fund's management at the time of the event. Other employees is the total number of employees of the fund complex that the fund is part of minus the number of portfolio managers minus the number of analysts. Fund / Retail banking / Retail insurance industry market share is the pre-event market share of the Swedish fund / retail banking / retail insurance industries. Retail outlets is a dummy variable that is 1 if the fund complex has retail outlets or branches (e.g., large banks or insurance companies), and 0 otherwise. News articles is the number of articles in newspapers and magazines (in the Affärsdata database) featuring or mentioning the fund during a one year pre-event period. Foreign fund is a dummy variable that is 1 if the fund complex that the fund is part of is registered outside of Sweden, and 0 otherwise. New fund is a dummy variable that is 1 if the fund was started less than three years prior to the event, and 0 otherwise. Past performance $[-T, 0)$ is the past raw returns in percent over a period of $T$ months. Dollar figures are based on the exchange rate of 10.04 kronor per dollar on 10/30/2000, the date of the launch of the system. 
Panel A: The dataset on portfolio choices

\begin{tabular}{ll}
\hline Total number of portfolio choices & $4,388,105$ \\
Size of people's stakes & \\
Total & $\$ 5.6$ billion \\
Mean & $\$ 1,265$ \\
Maximum & $\$ 2,639$ \\
Minimum & $\$ 10$ \\
\hline
\end{tabular}

Panel B: The dataset on fund advertising

\begin{tabular}{lcc}
\hline & Advertisements & Commercials \\
\hline $\mathrm{N}$ & 23,604 & 20,647 \\
Advertising expenditures & & \\
Total & $\$ 44.6$ million & $\$ 49.8$ million \\
Mean & $\$ 1,888$ & $\$ 2,413$ \\
Maximum & $\$ 46,434$ & $\$ 248,848$ \\
Minimum & $\$ 1.1$ & $\$ 72.2$ \\
Physical size of advertising & & \\
Maximum & Cover front of 34 story office building \\
Minimum & 1 x 8 lines & 8 min. $20 \mathrm{~s}$. \\
Media placement (\% of & & $2 \mathrm{~s}$. \\
advertising expenditures) & & \\
Print media & $89.2 \%$ & \\
Outdoor & $10.8 \%$ & $\mathrm{~N} / \mathrm{A}$ \\
Television & N/A & N/A \\
Radio & N/A & $5.6 \%$ \\
Movie theaters & N/A & $3.2 \%$ \\
\hline
\end{tabular}

\footnotetext{
${ }^{\mathrm{a}}$ This media category includes 279 different newspapers, popular press magazines, professional journals, and so on.
} 


\begin{tabular}{lcc}
\hline & Panel C: & \\
& Meand characteristics & \\
\hline Fund advertising & 205.1 & St. dev. \\
Fund manager experience & 11.1 & 226.6 \\
Fund manager tenure & 2.2 & 7.0 \\
Fund manager MBA & 0.222 & 3.0 \\
Specialized assets & 0.101 & 0.416 \\
Local fund complex & 0.530 & 0.302 \\
Distance to fund & 171.3 & 0.500 \\
Distance to fund assets & 344.1 & 294.9 \\
Log (Assets under management) & 5.49 & 396.6 \\
Log (Other employees) & 5.02 & 2.56 \\
Fund industry market share & 0.037 & 2.21 \\
Banking industry market share & 0.040 & 0.085 \\
Insurance industry market share & 0.034 & 0.090 \\
Retail outlets & 0.290 & 0.079 \\
News articles & 177.8 & 0.045 \\
New fund & 0.349 & 192.1 \\
Past performance [-12, 0) & 36.3 & 0.477 \\
\hline
\end{tabular}


Table 2

\section{Content analysis of fund advertising}

The table illustrates the range of content and message in fund advertising. I implement Resnik and Stern (1977) content analysis method and classify "cues" in fund ads into three broad categories: (i) Fee cue. A fund ad is considered to have a "price," i.e. fee, cue if it contains a reference to the fund's expense ratio. (ii) Performance cue. A fund ad has a performance cue if it contains the fund's return for some period (e.g., past year, 5 years or the fund's lifetime), Morningstar's star rating, other independent research company's rankings, or any other return comparison, with e.g. an index or category, chosen by the advertising fund itself. (iii) Other cue. These are ads that do not have a fee or performance cue. Operationally, I have implemented the content analysis by combining information available in the content description field in MarketWatch's database as well as information from the National Library of Sweden, which by law is required to store, indefinitely, one copy of all Swedish "published material" for research purposes. 
Panel A: Fund advertising with “price,” i.e. fee, cue

\begin{tabular}{ll}
\hline Content/message & Comments \\
\hline "If the price of milk goes up. Does it then taste better?” & $\begin{array}{l}\text { The graphical design of these ads was identical } \\
\text { to the design of the leading Swedish milk } \\
\text { producer's (Arla's) milk cartons }\end{array}$ \\
& $\begin{array}{l}\text { The ad contained no information on } \\
\text { cCompare our fees!” }\end{array}$ \\
& N/A \\
"We just cut our fees by 40\%” & N/A \\
"Higher pension thanks to our low charges" & N/A \\
\hline "Call us if you are tired of high expense ratios" & \\
\hline
\end{tabular}

Panel B: Fund advertising with performance cue

\begin{tabular}{ll}
\hline Content/message & Comments \\
\hline "A five-star investment” & Morningstar's 5-star rating was displayed \\
"Fund X has AAA rating" & N/A \\
"We have been Sweden's best fund manager SIX times” & The number 6 (six) is sex in Swedish \\
"Invest in this year's best fund manager" & N/A \\
"Words are good. Performance figures are better" & N/A \\
"We are number 1" & N/A \\
\hline
\end{tabular}

Panel C: Fund advertising with other cue than fee or performance

\begin{tabular}{|c|c|}
\hline Content/message & Comments \\
\hline "Harrison Ford can give you a better pension" & $\begin{array}{l}\text { In print ads and commercials between blocks at } \\
\text { the TV-premiere of the movie "Air Force One" } \\
\text { (starring Mr. Ford) }\end{array}$ \\
\hline "Absolut Strategi” & $\begin{array}{l}\text { The fund associated itself with top-shelf vodka } \\
\text { brand Absolut. For this, the fund was sued by } \\
\text { the Swedish vodka producer. The parties } \\
\text { settled, and the fund was renamed HQ.SE Total. }\end{array}$ \\
\hline "Hello, I’ve become a big, strong gorilla" & Ad for fund called "the Gorilla fund" \\
\hline "Our fund is your choice" & N/A \\
\hline "Asset management you can rely on" & N/A \\
\hline $\begin{array}{l}\text { "The right dose of medical competence and head for } \\
\text { business" }\end{array}$ & Ad for pharmaceutical fund \\
\hline "At a small fund manager, decisions are quicker" & N/A \\
\hline "Choose a large fund manager" & N/A \\
\hline "Invest in companies with the heart in Norrland" & "Norrland" = counties in the north of Sweden \\
\hline $\begin{array}{l}\text { "Stefan Edberg about our funds: Before I chose the best } \\
\text { tennis racket and the best coach. Now I choose funds." }\end{array}$ & $\begin{array}{l}\text { Retired tennis-pro Stefan Edberg endorses a } \\
\text { fund manager }\end{array}$ \\
\hline
\end{tabular}


Table 3

Fund advertising as direct information: Evidence from content analysis

The table reports statistics on the content of fund advertising. I implement Resnik and Stern (1977) content analysis method and classify "cues" in fund ads into three broad categories: (i) Fee cue. A fund ad is considered to have a "price," i.e. fee, cue if it contains a reference to the fund's expense ratio. (ii) Performance cue. A fund ad has a performance cue if it contains the fund's return for some period (e.g., past year, 5 years or the fund's lifetime), Morningstar's star rating, other independent research company's rankings, or any other return comparison, with e.g. an index or category, chosen by the advertising fund itself. (iii) Other cue. These are ads that do not have a fee or performance cue. Advertisements are fund advertisements appearing in more than 250 newspapers, and in the popular press and professional journals, as well as outdoor ads on billboards and busses, and in subway stations, etc. Commercials are fund commercials from all the major television and radio networks, and those appearing in the largest movie theaters.

\begin{tabular}{ll}
\hline Content & Percent of advertising expenditures \\
\hline All fund advertising: & 7.9 \\
Fee cue & 30.0 \\
Performance cue & 62.1 \\
Other cue & \\
Advertisements: & 13.5 \\
Fee cue & 43.2 \\
Performance cue & 43.3 \\
Other cue & \\
Commercials: & 2.9 \\
Fee cue & 18.2 \\
Performance cue & 79.0 \\
Other cue & \\
\hline
\end{tabular}




\section{Table 4}

\section{Evidence on fund advertising as a signal of quality}

The dependent variable is simple excess returns, i.e. a fund's annual return in percent minus the average annual return of all the funds in the fund's Morningstar category during the 12-month post-advertising period 11/1/2000 to 10/31/2001. Fund advertising is total fund advertising expenditures in thousands of dollars prior to the event. Performance advertising is fund advertising with a performance cue. The standard errors are corrected for clustering of the observations at the fund category level. $p$-values are given in parentheses below the coefficient estimates.

\begin{tabular}{lcccc}
\hline & $(1)$ & $(2)$ & $(3)$ & $(4)$ \\
\hline Fund advertising & -0.0051 & -0.0061 & -0.0138 & \\
& $(0.561)$ & $(0.368)$ & $(0.151)$ & \\
(Fund advertising) $/ 1,000$ & 0.0086 & 0.0091 & 0.0077 & \\
& $(0.177)$ & $(0.107)$ & $(0.243)$ & \\
Fund advertising & & & 0.0086 & \\
$\quad \times$ Quartile 4 advertising & & & $(0.159)$ & -0.0398 \\
Performance advertising & & & & $(0.107)$ \\
& & & & 29 \\
Fund category dummies & 29 & None & 0.264 & 0.301 \\
Adjusted R & & & 455 & 455 \\
$\mathrm{~N}$ & 0.260 & 455 & & \\
\hline
\end{tabular}


Table 5

Robustness checks: Fund advertising and signaling

The dependent variable in columns (1) and (2) is the intercept from regressing a mutual fund's monthly returns minus the risk-free rate on the monthly return of the fund's comparable Morningstar index minus the risk-free rate. The dependent variable in columns (3) - (8) is simple excess returns, i.e. a fund's annual return in percent minus the average annual return of all of the funds in the fund's Morningstar category during a postadvertising period. Fund advertising is total fund advertising expenditures in thousands of dollars prior to the event. Fund manager experience is the number of years of managerial experience in the fund industry. Fund manager tenure is the fund manager's length of tenure with the fund (in years). Fund manager MBA is a dummy variable that is 1 if the manager has an MBA, and 0 otherwise. New fund is a dummy variable that is 1 if the fund was started less than three years prior to the event, and 0 otherwise. News articles is the number of articles in newspapers and magazines (in the Affärsdata database) featuring or mentioning the fund during a one year pre-event period. Foreign fund is a dummy variable that is 1 if the fund complex that the fund is part of is registered outside of Sweden, and 0 otherwise. Specialized assets fund is a dummy variable that is 1 if the fund is a pharmaceutical fund, an IT and telecom fund, or an emerging markets fund, and 0 otherwise. The standard errors are corrected for clustering of the observations at the fund category level. p-values are given in parentheses below the coefficient estimates. 


\begin{tabular}{|c|c|c|c|c|c|c|c|c|}
\hline & (1) & (2) & (3) & (4) & (5) & (6) & (7) & (8) \\
\hline $\begin{array}{l}\text { Fund advertising } \\
\times \text { Quartile } 1 \text { fund manager experience }\end{array}$ & & & & $\begin{array}{r}-0.0041 \\
(0.288)\end{array}$ & & & & \\
\hline $\begin{array}{l}\text { Fund advertising } \\
\times \text { No fund manager MBA }\end{array}$ & & & & $\begin{array}{l}-0.0011 \\
(0.654)\end{array}$ & & & & \\
\hline $\begin{array}{l}\text { Fund advertising } \\
\times \text { New fund }\end{array}$ & & & & & $\begin{array}{l}-0.0015 \\
(0.599)\end{array}$ & & & \\
\hline $\begin{array}{l}\text { Fund advertising } \\
\times \text { Quartile } 1 \text { news articles }\end{array}$ & & & & & & $\begin{array}{r}-0.0062 \\
(0.198)\end{array}$ & & \\
\hline Fund category dummies & 29 & 29 & 29 & 29 & 29 & 29 & 29 & 29 \\
\hline Post-advertising period (months) & 12 & 36 & 36 & 12 & 12 & 12 & 12 & 12 \\
\hline Adjusted $\mathrm{R}^{2}$ & 0.294 & 0.342 & 0.239 & 0.263 & 0.294 & 0.295 & 0.299 & 0.294 \\
\hline $\mathrm{N}$ & 455 & 440 & 424 & 455 & 455 & 455 & 455 & 455 \\
\hline
\end{tabular}


Table 6

Evidence on fund advertising as mere exposure

The dependent variable is the natural log of dollar allocation to a fund. Fund advertising is total fund advertising expenditures in thousands of dollars prior to the event. Local fund complex is a dummy variable that is 1 if the fund complex that the fund is part of is registered in Sweden, and 0 otherwise. Distance to fund is the average flight time from Stockholm to the fund's headquarter in minutes (Swedish headquarters are defined to have zero distance). Distance to fund assets is market value weighted flight time from Stockholm to the fund's assets in minutes (Swedish assets are defined to have zero distance). Assets under management is total assets under the fund's management at the time of the event. Fund / Banking / Insurance industry market share is the pre-event market share of the Swedish fund / retail banking / retail insurance industries. News articles is the number of articles in newspapers and magazines (in the Affärsdata database) featuring or mentioning the fund during a one year pre-event period. Past performance [-T, 0 ) is the past raw returns in percent over a period of $T$ months. New fund is a dummy variable that is 1 if the fund is newly started. Past performance is defined to be zero for newly started funds. Based on the estimated coefficients in column 10, the "\% Effect" column reports the effect on the dollar allocation to the average fund (in percent) of changing each continuous (dummy) variable one standard deviation (from 0 to 1 ). The standard errors are corrected for clustering of the observations at the fund category level. $p$-values are given in parentheses below the coefficient estimates. 


\begin{tabular}{|c|c|c|c|c|c|c|c|c|c|c|c|}
\hline & (1) & (2) & (3) & (4) & (5) & (6) & (7) & (8) & (9) & (10) & \% Effect \\
\hline & & $(0.000)$ & $(0.005)$ & $(0.094)$ & $(0.015)$ & $(0.004)$ & $(0.020)$ & $(0.113)$ & $(0.161)$ & $(0.165)$ & \\
\hline Local fund complex & & & & $\begin{array}{c}1.072 \\
(0.000)\end{array}$ & & & & & & $\begin{array}{c}1.065 \\
(0.000)\end{array}$ & 1.90 \\
\hline Distance to fund assets & & & & & $\begin{array}{c}-0.0004 \\
(0.360)\end{array}$ & & & & & $\begin{array}{l}-0.0002 \\
(0.577)\end{array}$ & 0.08 \\
\hline Log (Assets under management) & & & & & & $\begin{array}{c}0.117 \\
(0.002)\end{array}$ & & & & $\begin{array}{c}0.211 \\
(0.000)\end{array}$ & 0.72 \\
\hline Fund ind. market share & & & & & & & $\begin{array}{c}2.110 \\
(0.151)\end{array}$ & & & $\begin{array}{c}0.872 \\
(0.444)\end{array}$ & 0.08 \\
\hline Banking ind. market share & & & & & & & $\begin{array}{c}4.805 \\
(0.004)\end{array}$ & & & $\begin{array}{c}2.574 \\
(0.060)\end{array}$ & 0.26 \\
\hline Past performance $[-12,0)$ & & & & & & & & & $\begin{array}{l}0.0182 \\
(0.000)\end{array}$ & $\begin{array}{l}0.0112 \\
(0.010)\end{array}$ & 0.58 \\
\hline New fund & & & & & & & & & & $\begin{array}{c}-0.078 \\
(0.687)\end{array}$ & 0.08 \\
\hline Fund category dummies & None & None & 29 & 29 & 29 & 29 & 29 & 29 & 29 & 29 & \\
\hline Adjusted $\mathrm{R}^{2}$ & 0.298 & 0.375 & 0.611 & 0.669 & 0.636 & 0.625 & 0.646 & 0.658 & 0.684 & 0.747 & \\
\hline $\mathrm{N}$ & 455 & 455 & 455 & 455 & 455 & 455 & 455 & 455 & 455 & 455 & \\
\hline
\end{tabular}




\section{Table 7}

\section{IV-estimation: Fund advertising, lagged fund advertising, and portfolio choices}

The estimation technique is 2SLS. The dependent variable in the first stage is fund advertising. The dependent variable in the second stage is the natural log of dollar allocation to a fund. Fund advertising is total fund advertising expenditures in thousands of dollars during the year prior to the event. Lagged fund advertising is total fund advertising expenditures in thousands of dollars during the period two years to one year prior to the event. Local fund complex is a dummy variable that is 1 if the fund complex that the fund is part of is registered in Sweden, and 0 otherwise. Distance to fund is the average flight time from Stockholm to the fund's headquarter in minutes (Swedish headquarters are defined to have zero distance). Distance to fund assets is market value weighted flight time from Stockholm to the fund's assets in minutes (Swedish assets are defined to have zero distance). Assets under management is total assets under the fund's management at the time of the event. Fund / Retail banking / Retail insurance industry market share is the pre-event market share of the Swedish fund / retail banking / retail insurance industries. News articles is the number of articles in newspapers and magazines (in the Affärsdata database) featuring or mentioning the fund during a one year pre-event period. Past performance $[-T, 0)$ is the past raw returns in percent over a period of $T$ months. New fund is a dummy variable that is 1 if the fund is newly started. Past performance is defined to be zero for newly started funds. Based on the estimated coefficients in the second-stage column, the "\% Effect" column reports the effect on the dollar allocation to funds (in percent) of changing each continuous (dummy) variable one standard deviation (from 0 to 1). The standard errors are corrected for clustering of the observations at the fund category level. $p$-values are given in parentheses below the coefficient estimates. 


\begin{tabular}{|c|c|c|c|}
\hline Dependent variable & $\begin{array}{c}\text { Fund } \\
\text { advertising }\end{array}$ & $\begin{array}{l}\text { Log of dollar } \\
\text { allocation to fund }\end{array}$ & \\
\hline & First stage & Second stage & $\%$ Effect \\
\hline Fund advertising & & $\begin{array}{l}0.0042 \\
(0.008)\end{array}$ & 1.59 \\
\hline Lagged fund advertising & $\begin{array}{c}0.792 \\
(0.000)\end{array}$ & & \\
\hline (Fund advertising) $^{2} / 1,000$ & $\begin{array}{c}0.803 \\
(0.000)\end{array}$ & $\begin{array}{r}-0.0050 \\
(0.028)\end{array}$ & 0.29 \\
\hline Local fund complex & $\begin{array}{c}47.51 \\
(0.001)\end{array}$ & $\begin{array}{c}1.114 \\
(0.001)\end{array}$ & 2.05 \\
\hline Distance to fund & $\begin{array}{l}-0.030 \\
(0.059)\end{array}$ & $\begin{array}{r}-0.0003 \\
(0.419)\end{array}$ & 0.09 \\
\hline Distance to fund assets & $\begin{array}{c}0.008 \\
(0.606)\end{array}$ & $\begin{array}{r}-0.0002 \\
(0.567)\end{array}$ & 0.08 \\
\hline Log (Assets under management) & $\begin{array}{c}0.943 \\
(0.505)\end{array}$ & $\begin{array}{c}0.202 \\
(0.000)\end{array}$ & 0.67 \\
\hline Fund industry market share & $\begin{array}{l}-34.75 \\
(0.652)\end{array}$ & $\begin{array}{c}0.703 \\
(0.655)\end{array}$ & 0.06 \\
\hline Banking industry market share & $\begin{array}{l}-162.46 \\
(0.040)\end{array}$ & $\begin{array}{c}2.561 \\
(0.083)\end{array}$ & 0.26 \\
\hline Insurance industry market share & $\begin{array}{c}67.56 \\
(0.218)\end{array}$ & $\begin{array}{c}1.431 \\
(0.195)\end{array}$ & 0.12 \\
\hline News articles & $\begin{array}{c}0.565 \\
(0.000)\end{array}$ & $\begin{array}{c}0.0034 \\
(0.019)\end{array}$ & 0.65 \\
\hline Past performance $[-12,0)$ & $\begin{array}{c}2.462 \\
(0.000)\end{array}$ & $\begin{array}{l}0.0128 \\
(0.009)\end{array}$ & 0.68 \\
\hline New fund & $\begin{array}{c}48.09 \\
(0.098)\end{array}$ & $\begin{array}{l}-0.104 \\
(0.329)\end{array}$ & 0.11 \\
\hline Fund category dummies & 29 & 29 & \\
\hline Adjusted $\mathrm{R}^{2}$ & 0.922 & 0.701 & \\
\hline $\mathrm{N}$ & 455 & 455 & \\
\hline
\end{tabular}


Table 8

Performance vs. other advertising and portfolio choices

The dependent variable is the natural log of dollar allocation to a fund. Performance advertising is fund advertising with a performance cue. Advertising with "other" cue is fund advertising with another cue than a fee or performance cue. Past performance $[-T, 0)$ is the past raw returns in percent over a period of $T$ months. New fund is a dummy variable that is 1 if the fund is newly started. Past performance is defined to be zero for newly started funds. Based on the estimated coefficients in column 3, the "\% Effect" column reports the effect on the dollar allocation to funds (in percent) of changing each continuous (dummy) variable one standard deviation (from 0 to 1). Control variables refer to the set of control variables used in the last column of Table 7. The standard errors are corrected for clustering of the observations at the fund category level. $p$ values are given in parentheses below the coefficient estimates.

\begin{tabular}{lcccc}
\hline & $(1)$ & $(2)$ & $(3)$ & \% Effect \\
\hline Performance advertising & 0.0060 & & 0.0063 & 0.52 \\
& $(0.024)$ & & $(0.012)$ & \\
Advertising with “other cue” & & 0.0035 & 0.0029 & 0.79 \\
& & $(0.000)$ & $(0.000)$ & \\
Past performance [-12, 0) & 0.0181 & & 0.0160 & 0.92 \\
& $(0.000)$ & & $(0.001)$ & \\
New fund & -0.079 & & -0.135 & -0.14 \\
& $(0.574)$ & & $(0.499)$ & \multirow{2}{*}{0.224} \\
Performance advertising / 1,000 & & & $(0.001)$ & \\
$\quad \times$ Past performance [-12, 0) & & & 29 & \\
Fund category dummies & 29 & 29 & 0.758 & \\
Adjusted R & 0.728 & 0.672 & Yes & \\
Control variables & Yes & Yes & 455 & \\
N & 455 & 455 & & \\
\hline
\end{tabular}


Table 9

\section{The effect of advertising on portfolio returns}

The dependent variable is a fund's annual expense ratio in percent. Fund advertising is total fund advertising expenditures in thousands of dollars prior to the event. Assets under management is total assets under the fund's management at the time of the event. Other employees is the total number of employees of the fund complex that the fund is part of minus the number of portfolio managers minus the number of analysts. Retail outlets is a dummy variable that is 1 if the fund complex has retail outlets or branches (e.g., large banks or insurance companies), and 0 otherwise. Based on the estimated coefficients in column 4, the "b.p. Effect" column reports the effect on a fund's expense ratio (in basis points per year) of changing each continuous (dummy) variable one standard deviation (from 0 to 1 ). The standard errors are corrected for clustering of the observations at the fund category level. $p$-values are given in parentheses below the coefficient estimates.

\begin{tabular}{lccccc}
\hline & $(1)$ & $(2)$ & $(3)$ & $(4)$ & b.p. Effect \\
\hline Fund advertising & 0.0023 & 0.0021 & 0.0021 & 0.0022 & 50 \\
& $(0.016)$ & $(0.025)$ & $(0.022)$ & $(0.011)$ & \\
Log (Assets under management) & & 0.0035 & & 0.0055 & 1 \\
& & $(0.699)$ & & $(0.571)$ & \\
Log (Other employees) & & 0.0426 & & 0.0425 & 9 \\
& & $(0.006)$ & & $(0.004)$ & 11 \\
Retail outlets & & & 0.1038 & 0.1074 & \\
& 29 & 29 & 29 & 29 & \\
Fund category dummies & 0.534 & 0.549 & 0.536 & 0.552 & \\
Adjusted R & 455 & 455 & 455 & 455 & \\
$\mathrm{~N}$ & & & & \\
\hline
\end{tabular}


Table 10

The effect of advertising on portfolio risk

The table compares an advertising-induced portfolio and the default fund. The data are from Morningstar or hand-collected from funds' annual reports. Hot market segment is defined as the industry that had the highest raw returns during a three-year period prior to the reform (IT and high-tech stocks). The default fund is the fund chosen for those who did not actively choose any funds on their own. The advertising-induced portfolio is a portfolio constructed by investing in different funds in proportion to their levels of advertising expenditures.

\begin{tabular}{lcc}
\hline Risk characteristics & Default fund & Advertising-induced portfolio \\
\hline Asset allocation & & \\
Equities & $82.0 \%$ & $98.9 \%$ \\
Fixed-income securities & $10.0 \%$ & $1.1 \%$ \\
Other & $8.0 \%$ & $0 \%$ \\
Indexing & $60.0 \%$ & $0.4 \%$ \\
Hot market segment & $30.1 \%$ & $60.5 \%$ \\
Asset (equities) location & & \\
Sweden & $20.7 \%$ & $81.2 \%$ \\
Europe & $24.4 \%$ & $2.9 \%$ \\
Americas & $42.7 \%$ & $13.2 \%$ \\
Asia & $12.2 \%$ & $2.7 \%$ \\
$\mathrm{~N}$ & 1 & 455 \\
\hline
\end{tabular}


Figure 1

Survey evidence on fund advertising recall

The figure shows survey evidence on people's fund advertising recall ratios. The survey of 1,083 retirement savers between the age of 20 and 62 (selected to be representative of the population) was implemented by a leading phone survey company (Sifo) during the days following people's initial portfolio choices.

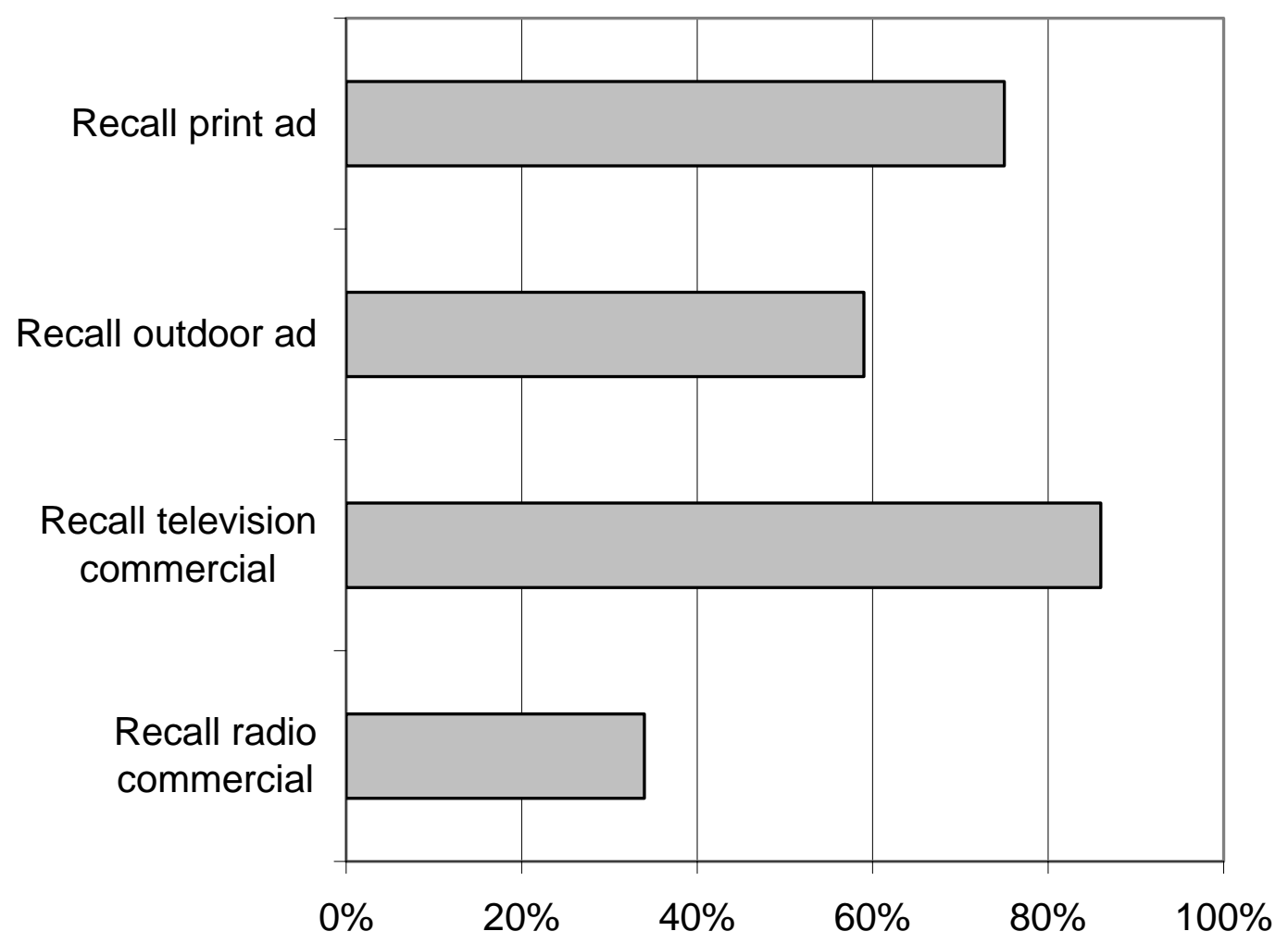


Figure 2

Fund advertising and active portfolio choices 2000-2005

The figure shows the aggregate amount of fund advertising and the proportion of active portfolio choices each year during the period 2000-2005. The data on portfolio choices come from the Premium Pension Authority. The data on fund advertising come from MarketWatch.

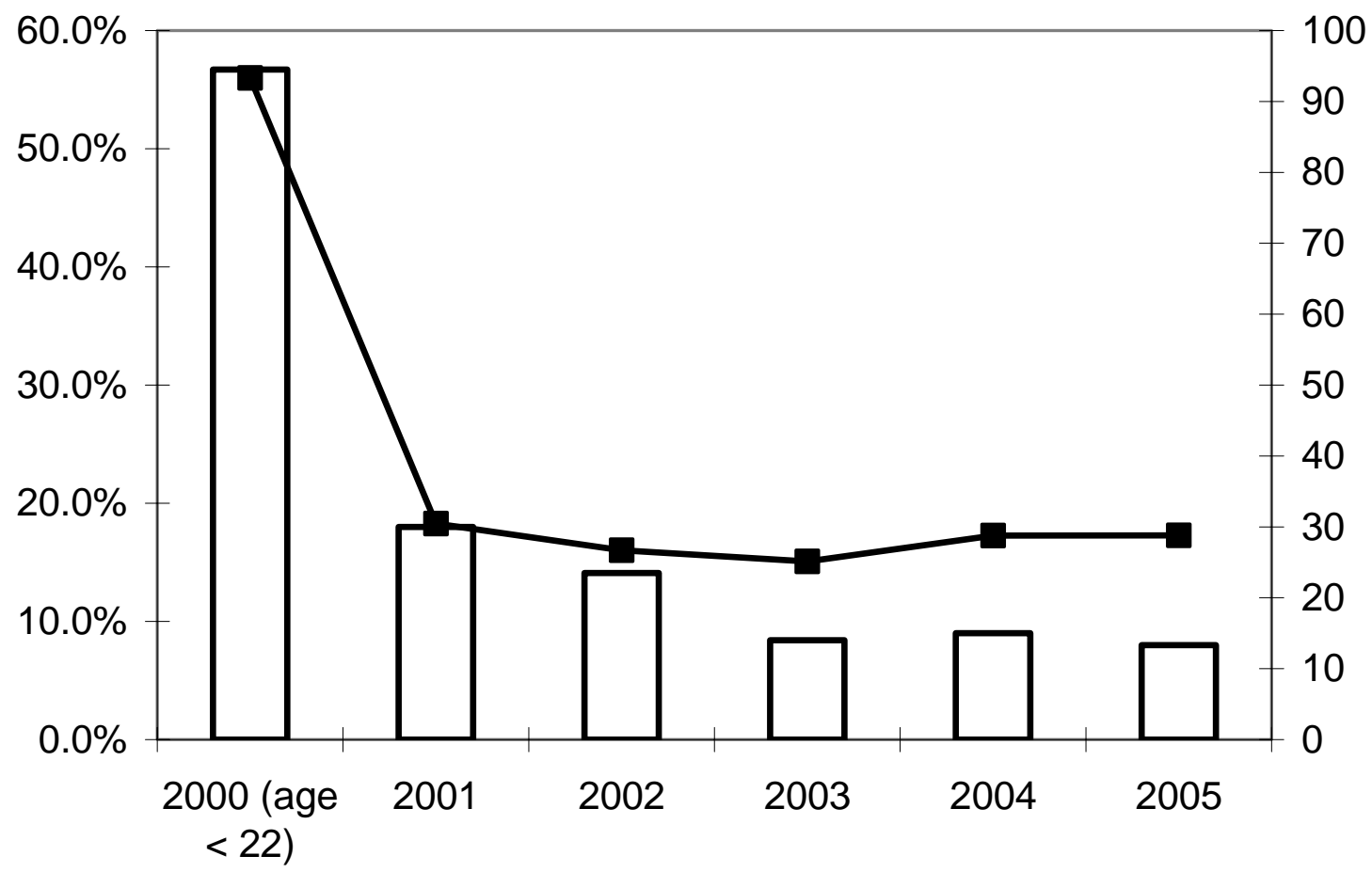

Active choices (\%) $\rightarrow$-Fund advertising (million dollars) 
Figure 3

Fund advertising and fund choices in year 2000

The figure shows the amount of fund advertising and the amount of dollars allocated to the funds at the year 2000 launch of the reformed social security reform in Sweden. The data on portfolio choices come from the Premium Pension Authority. The data on fund advertising come from MarketWatch.

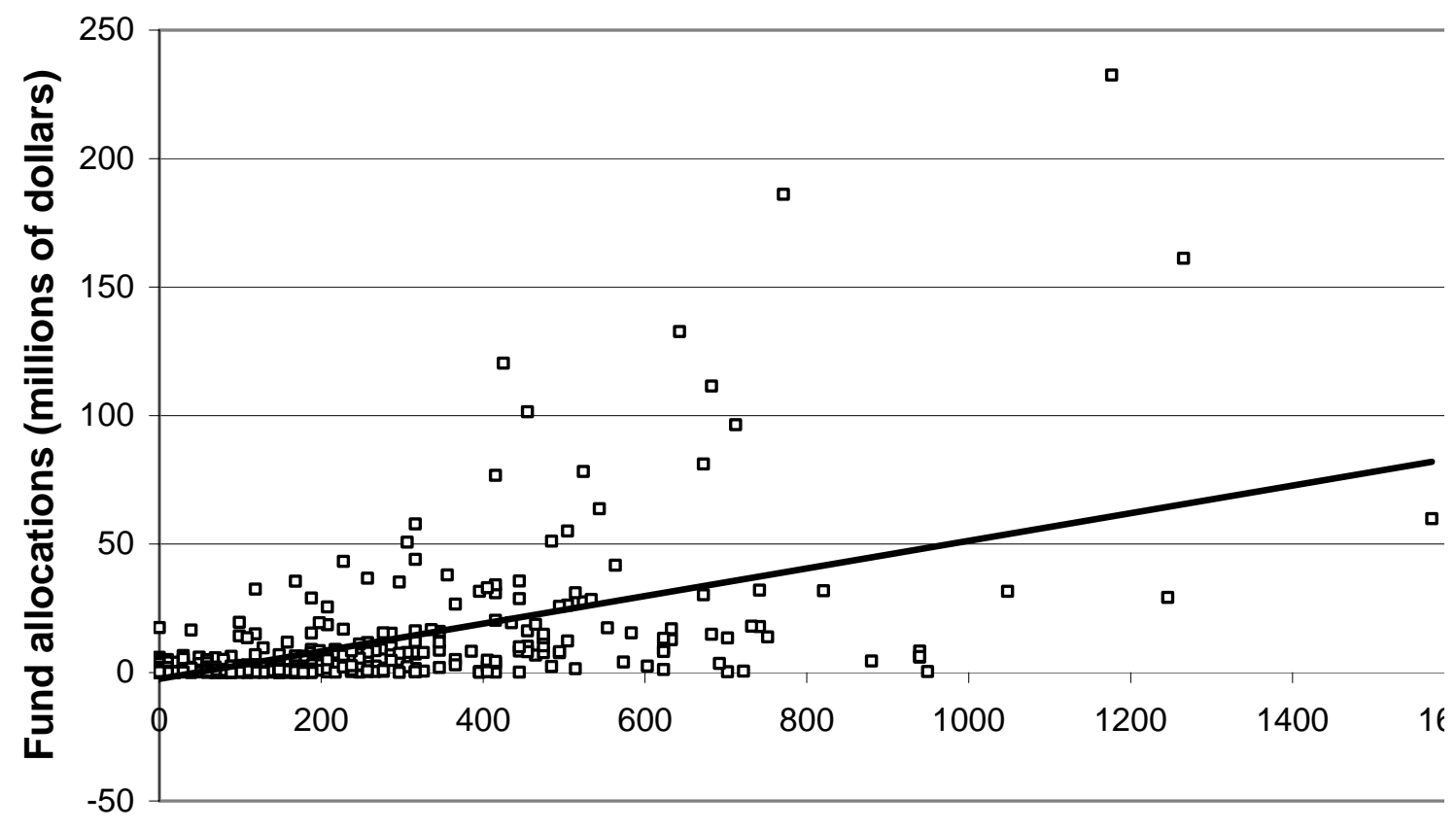

Advertising expenditures (thousands of dollars) 
Our papers can be downloaded at:

$\underline{\text { http://cerp.unito.it }}$

\section{CeRP Working Paper Series}

\begin{tabular}{|c|c|c|}
\hline $\mathrm{N}^{\circ} 1 / 00$ & Guido Menzio & Opting Out of Social Security over the Life Cycle \\
\hline $\mathrm{N}^{\circ} 2 / 00$ & $\begin{array}{l}\text { Pier Marco Ferraresi } \\
\text { Elsa Fornero }\end{array}$ & $\begin{array}{l}\text { Social Security Transition in Italy: Costs, Distorsions and (some) } \\
\text { Possible Correction }\end{array}$ \\
\hline $\mathrm{N}^{\circ} 3 / 00$ & $\begin{array}{l}\text { Emanuele Baldacci } \\
\text { Luca Inglese }\end{array}$ & $\begin{array}{l}\text { Le caratteristiche socio economiche dei pensionati in Italia. } \\
\text { Analisi della distribuzione dei redditi da pensione (only available } \\
\text { in the Italian version) }\end{array}$ \\
\hline $\mathrm{N}^{\circ} 4 / 01$ & Peter Diamond & Towards an Optimal Social Security Design \\
\hline $\mathrm{N}^{\circ} 5 / 01$ & Vincenzo Andrietti & $\begin{array}{l}\text { Occupational Pensions and Interfirm Job Mobility in the } \\
\text { European Union. Evidence from the ECHP Survey }\end{array}$ \\
\hline$N^{\circ} 6 / 01$ & Flavia Coda Moscarola & $\begin{array}{l}\text { The Effects of Immigration Inflows on the Sustainability of the } \\
\text { Italian Welfare State }\end{array}$ \\
\hline $\mathrm{N}^{\circ} 7 / 01$ & Margherita Borella & $\begin{array}{l}\text { The Error Structure of Earnings: an Analysis on Italian } \\
\text { Longitudinal Data }\end{array}$ \\
\hline $\mathrm{N}^{\circ} 8 / 01$ & Margherita Borella & $\begin{array}{l}\text { Social Security Systems and the Distribution of Income: an } \\
\text { Application to the Italian Case }\end{array}$ \\
\hline$N^{\circ} 9 / 01$ & Hans Blommestein & $\begin{array}{l}\text { Ageing, Pension Reform, and Financial Market Implications in } \\
\text { the OECD Area }\end{array}$ \\
\hline $\mathrm{N}^{\circ} 10 / 01$ & $\begin{array}{l}\text { Vincenzo Andrietti and Vincent } \\
\text { Hildebrand }\end{array}$ & $\begin{array}{l}\text { Pension Portability and Labour Mobility in the United States. } \\
\text { New Evidence from the SIPP Data }\end{array}$ \\
\hline $\mathrm{N}^{\circ} 11 / 01$ & $\begin{array}{l}\text { Mara Faccio and Ameziane } \\
\text { Lasfer }\end{array}$ & $\begin{array}{l}\text { Institutional Shareholders and Corporate Governance: The Case } \\
\text { of UK Pension Funds }\end{array}$ \\
\hline$N^{\circ} 12 / 01$ & Roberta Romano & $\begin{array}{l}\text { Less is More: Making Shareholder Activism a Valuable } \\
\text { Mechanism of Corporate Governance }\end{array}$ \\
\hline $\mathrm{N}^{\circ} 13 / 01$ & Michela Scatigna & Institutional Investors, Corporate Governance and Pension Funds \\
\hline $\mathrm{N}^{\circ} 14 / 01$ & Thomas H. Noe & Investor Activism and Financial Market Structure \\
\hline$N^{\circ} 15 / 01$ & Estelle James & $\begin{array}{l}\text { How Can China Solve ist Old Age Security Problem? The } \\
\text { Interaction Between Pension, SOE and Financial Market Reform }\end{array}$ \\
\hline$N^{\circ} 16 / 01$ & $\begin{array}{l}\text { Estelle James and } \\
\text { Xue Song }\end{array}$ & $\begin{array}{l}\text { Annuities Markets Around the World: Money's Worth and Risk } \\
\text { Intermediation }\end{array}$ \\
\hline$N^{\circ} 17 / 02$ & $\begin{array}{l}\text { Richard Disney and } \\
\text { Sarah Smith }\end{array}$ & $\begin{array}{l}\text { The Labour Supply Effect of the Abolition of the Earnings Rule } \\
\text { for Older Workers in the United Kingdom }\end{array}$ \\
\hline$N^{\circ} 18 / 02$ & Francesco Daveri & $\begin{array}{l}\text { Labor Taxes and Unemployment: a Survey of the Aggregate } \\
\text { Evidence }\end{array}$ \\
\hline $\mathrm{N}^{\circ} 19 / 02$ & $\begin{array}{l}\text { Paolo Battocchio } \\
\text { Francesco Menoncin }\end{array}$ & $\begin{array}{l}\text { Optimal Portfolio Strategies with Stochastic Wage Income and } \\
\text { Inflation: The Case of a Defined Contribution Pension Plan }\end{array}$ \\
\hline$N^{\circ} 20 / 02$ & Mauro Mastrogiacomo & Dual Retirement in Italy and Expectations \\
\hline$N^{\circ} 21 / 02$ & $\begin{array}{l}\text { Olivia S. Mitchell } \\
\text { David McCarthy }\end{array}$ & Annuities for an Ageing World \\
\hline
\end{tabular}


Chris Soares Mark Warshawsky

$\mathrm{N}^{\circ} 23 / 02 \quad$ Ermanno Pitacco

$\mathrm{N}^{\circ}$ 24/02 Laura Ballotta Steven Haberman

$\mathrm{N}^{\circ} 25 / 02$ Edmund Cannon Ian Tonks

$N^{\circ} 26 / 02 \quad$ E. Philip Davis

$N^{\circ}$ 27/02 Reinhold Schnabel

N ${ }^{\circ} 28 / 02 \quad$ Luca Spataro

N ${ }^{\circ} 29 / 02 \quad$ Marco Taboga

$\mathrm{N}^{\circ} 30 / 03 \quad$ Bas Arts

Elena Vigna

№ 31/03 Giacomo Ponzetto

N ${ }^{\circ} 32 / 04 \quad$ Angelo Marano

Paolo Sestito

$\mathrm{N}^{\circ} 33 / 04 \quad$ Elsa Fornero

Carolina Fugazza

Giacomo Ponzetto

N 34/04 Chourouk Houssi

$\mathrm{N}^{\circ}$ 35/04 Monika Bütler

Olivia Huguenin

Federica Teppa

$N^{\circ} 36 / 04 \quad$ Laurence J. Kotlikoff

$N^{\circ} 37 / 04 \quad$ Jay Ginn

№ 38/05 Carolina Fugazza

Federica Teppa

No 39/05 Anna Rita Bacinello

$N^{\circ} 40 / 05 \quad$ Carolina Fugazza

Massimo Guidolin

Giovanna Nicodano

$\mathrm{N}^{\circ}$ 41/05 Massimo Guidolin

Giovanna Nicodano

$\mathrm{N}^{\circ} 42 / 05 \quad$ Margherita Borella

Flavia Coda Moscarola

$\mathrm{N}^{\circ} 43 / 05 \quad$ John Beshears

James J. Choi

David Laibson

Brigitte C. Madrian
Annuity Risk: Volatility and Inflation Exposure in Payments from Immediate Life Annuities

Longevity Risk in Living Benefits

Valuation of Guaranteed Annuity Conversion Options

The Behaviour of UK Annuity Prices from 1972 to the Present

Issues in the Regulation of Annuities Markets

Annuities in Germany before and after the Pension Reform of 2001

New Tools in Micromodeling Retirement Decisions: Overview and Applications to the Italian Case

The Realized Equity Premium has been Higher than Expected: Further Evidence

A Switch Criterion for Defined Contribution Pension Schemes

Risk Aversion and the Utility of Annuities

Older Workers and Pensioners: the Challenge of Ageing on the Italian Public Pension System and Labour Market

A Comparative Analysis of the Costs of Italian Individual Pension Plans

Le Vieillissement Démographique :

Problématique des Régimes de Pension en Tunisie

What Triggers Early Retirement. Results from Swiss Pension Funds

Pensions Systems and the Intergenerational Distribution of Resources

Actuarial Fairness or Social Justice?

A Gender Perspective on Redistribution in Pension Systems

An Empirical Assessment of the Italian Severance Payment (TFR)

Modelling the Surrender Conditions in Equity-Linked Life Insurance

Investing for the Long-Run in European Real Estate. Does

Predictability Matter?

Small Caps in International Equity Portfolios: The Effects of Variance Risk.

Distributive Properties of Pensions Systems: a Simulation of the Italian Transition from Defined Benefit to Defined Contribution

The Importance of Default Options for Retirement Saving

Outcomes:

Evidence from the United States 
